\title{
Systematic studies in the eucalypts - 3 New taxa and combinations in Eucalyptus (Myrtaceae)
}

\author{
K.D. Hill and L.A.S. Johnson
}

\begin{abstract}
Hill, K.D., and Johnson, L.A.S. (National Herbarium of New South Wales, Royal Botanic Gardens, Sydney, NSW, Australia 2000) 1991. Systematic studies in the eucalypts - 3. New taxa and combinations in Eucalyptus (Myrtaceae). Telopea 4(2): 223-267. A number of new taxa are described at specific and subspecific rank, and other changes to names and status are made. New species are E. disclusa L. Johnson \& Blaxell, E. vicina L. Johnson \& K. Hill, E. lockyeri Blaxell \& K. Hill, E. alligatrix L. Johnson \& K. Hill, E. conspicua L. Johnson \& K. Hill, E. paedoglauca L. Johnson \& Blaxell, E. prominula L. Johnson \& K. Hill, E. tenella L. Johnson \& K. Hill, E. ralla L. Johnson \& K. Hill, E. imitans L. Johnson \& K. Hill, E. spectatrix L. Johnson \& Blaxell, E. Jaophila L. Johnson \& Blaxell, E. obstans L. Johnson \& K. Hill (formerly known as E. obtusiflora auct. non. DC.), E. langleyi L. Johnson \& Blaxell, E. copulans L. Johnson \& K. Hill, E. serpentinicola L. Johnson \& Blaxell and E. lacrimans L. Johnson \& K. Hill. The new name E. paroula L. Johnson \& K. Hill is provided for E. parvifolia Cambage, non Newberry. New subspecies are described in Eucalyptus parramattensis C. Hall (subsp. decadens L. Johnson \& Blaxell), E. rubida Deane \& Maiden (subspp. canobolensis L. Johnson \& K. Hill, septemflora L. Johnson \& K. Hill, and barbigerorum L. Johnson \& K. Hill) and E. caleyi (subsp. ovendenii). E. tricarpa (L. Johnson) L. Johnson \& K. Hill is elevated to specific rank (formerly a subspecies of E. sideroxylon Cunn. ex Woolls). E. pulverulenta Sims var. lanceolata Howitt is lectotypified in order to place it unequivocally into the synonymy of E. cephalocarpa Blakely.
\end{abstract}

\section{Introduction}

New taxa described here are a small selection of a large number that have been defined during an overall revision of the eucalypts now in progress. These are mainly taxa occurring in New South Wales, which we need to publish in order to validate names for use in the forthcoming second volume of the Flora of New South Wales. A number of other new species from New South Wales have already been described by Johnson \& Hill (1990). At this stage, Eucalyptus L'Hérit. will be used in the traditional sense. The species are not allocated alphabetic codes according to the system of Pryor \& Johnson (1971), since these are being revised. Species are treated in the order in which they occur in the revised classification being developed from that of Pryor \& Johnson.

Rare or threatened species are allocated conservation status codes according to the system of Briggs \& Leigh (1988).

\section{Terminology}

The term 'stemonophore' is used throughout as a more acceptable combination of Greek elements than the Latin-Greek hybrid 'staminophore' (after Johnson \& Briggs 1984).

The term 'calyptra' is used throughout in place of 'operculum' as traditionally used in Eucalyptus. The latter term has been used in Eucalyptus alone, whereas the former 
is the accepted term for fused perianth structures occurring widely in Myrtaceae (Johnson \& Briggs 1984, following McVaugh 1968). The calyptra in all Monocalyptus taxa is described as 'appearing single' in reference to the actually complex nature and origin of this structure, to be discussed elsewhere.

The hairs on juvenile leaves of stringybark taxa are described as 'stellate hairs' for brevity. These are not stellate hairs as occurring in for example certain Chenopodiaceae, but distinctive structures in which a number of simple hairs arise from a raised oil gland (discussed by Johnson (1972) and Ladiges (1984)).

Bark is described as 'persistent' in cases where it is not regularly shed, and 'smooth' when regularly shedding. The former includes 'stringybark', 'box' and 'ironbark' among other types, and the latter covers the 'gum' barks.

Species authorship is to be cited as presented under each taxon described. They are not cases for the use of 'ex'.

1. Eucalyptus parramattensis C. Hall, Proc. Linn. Soc. New South Wales 37: 568, pl. 60,61 (1913).

TrPe CITATron: 'Hab - Fairfield, Cabramatta, Auburn (C. Hall), Milton (R. T. Baker), all in New South Wales.'

Type: New South Wales: Central Coast: near Public School, Fairfield, C. Hall (lecto NSW).

Typification established by Maiden (Crit. Revis. Eucalyptus 4: 38 (1917)).

[E. tereticornis Sm. var. amblycorys F. Muell. ex Maiden, Crit. Revis. Eucalyptus 4: 15 (1917), in part, pro. syn., nom. invalid. Discussed under E. prava L. Johnson \& K. Hill (Johnson \& Hill 1990).]

Tree to $15 \mathrm{~m}$ tall. Bark regularly shedding but showing a rough and granular texture, patchy grey, brownish grey, orange and pinkish white, often shedding irregularly. Adult leaves disjunct, stiff, usually falcate, lanceolate, $7-20 \mathrm{~cm}$ long, $1.0-3.5 \mathrm{~cm}$ wide; lateral veins irregular, reticulate, at $30^{\circ}$ to $50^{\circ}$ to midrib, intramarginal vein distinct, to $2.5 \mathrm{~mm}$ from margin; petiole $10-25 \mathrm{~mm}$ long, grooved above. Umbellasters axillary, 7- flowered; peduncles 2- or 3-angled, 5-10 mm long; pedicels angled, 2-8 mm long. Mature buds 6-10 mm long, 3-6 mm wide; calyptra $1 \frac{1 / 2}{2}$ to $2 \frac{1}{2}$ times longer than hypanthium, rounded, obtuse, often wider than hypanthium at widest point; outer calyptra scar distinct, outer calyptra sometimes present on near mature buds. Fruits campanulate or hemispherical, 5-7 mm long, 5-9 mm diam., 3- or 4-locular with prominently exserted broadly triangular sometimes tapered valves; calyptra scars forming a distinct ridged band 1-2 mm wide around hypanthium; disc narrow, distinct from hypanthium, raised and incurved to enclose bases of valves. Seeds brown, glossy, angular, to $1 \mathrm{~mm}$ long; chaff similar, longer and thinner.

Two allopatric subspecies may be recognised within E. parramattensis.

\section{Key to the subspecies}

1 Fruits $<7$ mm diameter 1A. subsp. parramattensis

$1^{*}$ Fruits $>7 \mathrm{~mm}$ diameter 1B. subsp. decadens

\section{A. Eucalyptus parramattensis $C$. Hall subsp. parramattensis}

= E. parramattensis C. Hall var. sphaerocalyx Blakely, Key Eucalypts: 133 (1934). TYPE CITATION: 'N.S.W. - Duck River, Parramatta (Dr. Woolls); Richmond, Bankstown and 
Cabramatta.' TYPE: New South WALES: Central Coast: Duck River, Parramatta, Woolls (holo NSW). Although Blakely cited other localities, this was the single specimen fully cited, and was also the single specimen labelled 'Type' by Blakely. Included in E. parramattensis by Pryor \& Johnson (1971).

[E. tereticornis Sm. var. sphaerocalyx F. Muell. ex Maiden, Crit. Revis. Eucalyptus 4: 316 (1917), pro. syn., nom. invalid. This name was applied to specimens collected at 'Duck Creek' [Duck River], Parramatta, by Woolls, i.e. the type material of E. parramattensis var. sphaerocalyx Blakely (see above).]

Tree to $15 \mathrm{~m}$ tall. Adult leaves $7-15 \mathrm{~cm}$ long, $1-2 \mathrm{~cm}$ wide; intramarginal vein to 1 $\mathrm{mm}$ from margin; petiole $10-20 \mathrm{~mm}$ long. Peduncles $5-10 \mathrm{~mm}$ long; pedicels 2-8 $\mathrm{mm}$ long. Mature buds 5-8 mm long, 4-5 mm wide. Fruit 3-5 mm long, 5-7 mm diam.

Distribution: from east of Mudgee to near Hilltop, with extensive stands in the region between the Hunter and Culoul Ranges (Figure 1).

ECOLOGY: this taxon characteristically occurs on infertile sandy soils, often on sites of impeded drainage.

Hybrids are recorded with E. longifolia Link, E. resinifera Smith subsp. resinifera and E. punctata DC.

CONSERVATION STATUS: not considered to be at risk.

Selected specimens (from 77 examined): New South Wales: Central Coast: Howes Valley, Cambage 1526, 8 Jul 1906 (NSW); $10.2 \mathrm{~km} \mathrm{~N}$ of Mellong Ck on Putty road, Brooker 5934, 28 Apr 1978 (CANB, NSW); SW corner of Castlereagh State Forest, Coveny 11884 \& Goodwin, 13 Sep 1984 (NSW, BRI, CANB, CBG, K, MEL, PERTH); $1.5 \mathrm{~km} \mathrm{~S}$ of Agnes Banks, Crisp 7484, Taylor \& Weston, 29 Oct 1984 (CBG, AD, NSW); Cabramatta, Boorman, Jul 1917 (NSW); Douglas Park, Johnson NSW 84442, 21 Nov 1965; Shepherds Swamp, Hilltop, Maiden E Boorman, Sep 1902 (NSW). Central Western Slopes: Munghorn, Ingram, 15 Apr 1952 (NSW); 5 miles $[8 \mathrm{~km}] \mathrm{N}$ of Ulan on Cassilis road, Johnston 59 \& Vos, 5 Nov 1968 (CANB, NSW); c. 3-4 miles [5-6 km] SE of Kindalwry Mtn, S of Rylstone, Johnson 4515, 3 Oct 1965 (NSW).

1B. Eucalyptus parramattensis C. Hall subsp. decadens L. Johnson $\mathcal{E}$ Blaxell, subsp. nov.

Ab subspecie typica alabastris fructibus foliisque omnibus majoribus.

TYPe: New South Wales: North Coast: 1 mile $[1.6 \mathrm{~km}] \mathrm{W}$ of Saltash on Raymond Terrace road, L.A.S. Johnson, 15 Apr 1964 (holo NSW 228221).

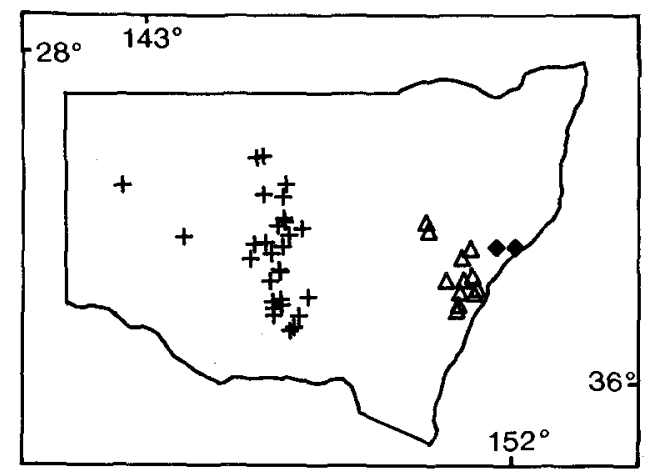

Figure 1. Distribution of E. parramattensis $C$. Hall subsp. parramattensis $(\triangle)$, E. parramattensis subsp. decadens $(\bullet)$ and E. vicina $(+)$. 
Tree to $10 \mathrm{~m}$ tall, usually less than $7 \mathrm{~m}$. Adult leaves $10-20 \mathrm{~cm}$ long, $1.5-3.5 \mathrm{~cm}$ wide; intramarginal vein to $2.5 \mathrm{~mm}$ from margin; petiole $15-25 \mathrm{~mm}$ long. Peduncles $7-10$ $\mathrm{mm}$ long; pedicels 3-7 mm long. Mature buds 7-10 $\mathrm{mm}$ long, 4-6 mm wide. Fruit 5-7 mm long, 7-9 mm diam. Figure 2.

Subspecies decadens is distinguished from E. parramattensis subsp. parramattensis by its larger buds, fruits and leaves.

Distribution: New South Wales: Lower Hunter Valley, Williamtown and Kurri Kurri districts (Figure 1).

ECOLOGY: E. parramattensis subsp. decadens is restricted to low-lying, often swampy areas on poor sandy soils. It is associated with E. signata F. Muell., E. globoidea Blakely and Angophora bakeri C. Hall.

The epithet is from the Latin decadens, falling down, referring to the general 'tumbledown gum' habit of the trees. Since it was drawn to attention by the late Rod W. Earp, it has been familiarly known to L. Johnson and associates as 'Earp's Dirty Gum', alluding to the 'dirty grey' bark.

CONSERVATION STATUS: $2 \mathrm{~V}$. Under significant threat from residential development.

SeleCted SPECIMENS (from 14 examined): NeW Sourh Wales: North Coast: Williamtown, Earp, 29 Dec 1955 (NSW), Johnson, 27 Jan 1962 (NSW); Tomago, Bartrim, Sep 1979 (NSW); 1 km NE of Kurri Kurri, B.G. Briggs 3280 \& Johnson, 15 Mar 1970 (NSW).

\section{Eucalyptus disclusa L. Johnson \& Blaxell, sp. nov.}

$\mathrm{Ab}$ E. seeana distinguitur: folia adulta juveniliaque latiora, fructus major disco plus elevato, calyptra longior angustiorque.

TyPE: QueENSLAND: Rainbow Falls, Blackdown Tableland, M.I.H. Brooker 3776, 31 Aug 1972 (holo NSW; iso CANB).

Tree to $12 \mathrm{~m}$ tall, usually less than $8 \mathrm{~m}$. Bark smooth, dark grey or brownish grey, with paler patches. Seedling leaves petiolate, ovate, rounded, opposite for about 7 nodes. Juvenile leaves petiolate, ovate, acute or acuminate, disjunct, to $12 \mathrm{~cm}$ long, $6.5 \mathrm{~cm}$ wide. Adult leaves lanceolate, slighty falcate, $8-18 \mathrm{~cm}$ long, $15-30 \mathrm{~mm}$ wide; petiole 20-30 mm long; lateral veins irregular, reticulate, at $30^{\circ}-45^{\circ}$ to midrib; intra-marginal vein distinct, $1-3 \mathrm{~mm}$ from margin, with reticulate secondary veins between margin and intramarginal vein. Umbellasters axillary, usually 7-flowered, occasionally 11-flowered; peduncles terete or 2-angled, 10-20 mm long; pedicels 5-8 mm long. Mature buds $12-15 \mathrm{~mm}$ long, 3-5 mm diam.; calyptra 31/2 -6 times longer than hypanthium, evenly conical and acute; outer calyptra shed when buds small, scar prominent. Stamens all fertile; filaments upright, not inflexed in bud; anthers ovoid, dorsifixed, versatile, dehiscing by slits. Fruits globular, 5-7 mm long, 5-7 mm diam., 3-4-locular; calyptra scar and stemonophore visible on most fruits as narrow bands around top of hypanthium; disc narrow, raised, ultimately incurved or horizontal, sometimes enclosing valve bases; valves broadly triangular, vertically exserted. Seeds dark brown, dull, angular, 0.5-0.8 mm long; chaff similar, longer, thinner. Figure 3.

E. disclusa is nearest to E. seeana Maiden, from which it is distinguished by the ovate juvenile leaves (lanceolate in the latter), lanceolate adult leaves (narrow-lanceolate in the latter), larger fruits (to $5 \mathrm{~mm}$ long in the latter) with more raised disc, and longer, narrower calyptra (usually less than 3 times longer than hypanthium in the latter).

Distribution: QueEnsland: Blackdown Tableland, Leichhardt District, west of Rockhampton (Figure 4). 


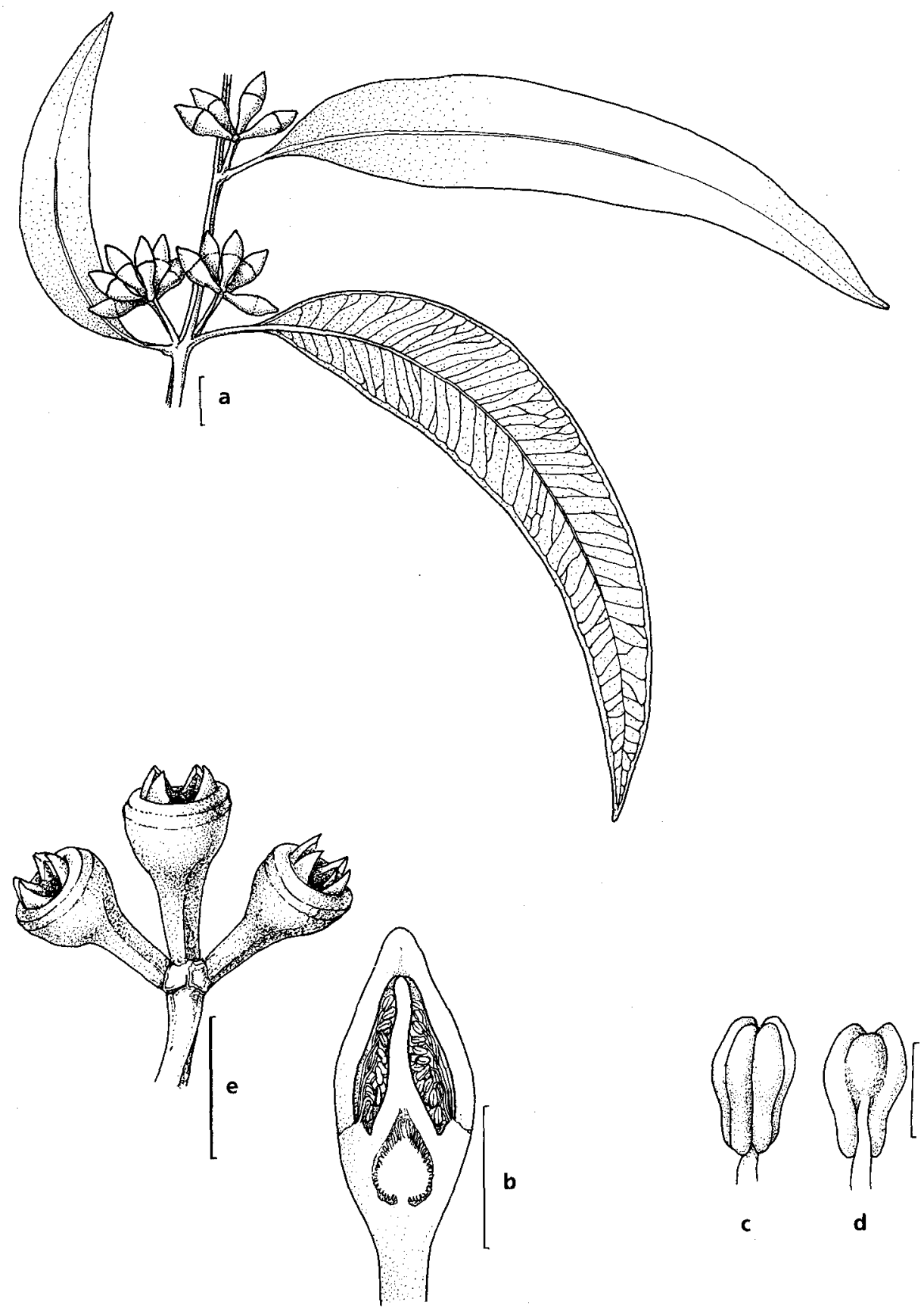

Figure 2. E. parramattensis subsp. decadens. a, adult leaves and buds. $\mathbf{b}$, median section of bud. $\mathbf{c}$, $\mathrm{d}$, anther. e, fruit (all from Johnson, 27 Jan 1962). Scale bar: $\mathrm{a}, \mathrm{e}=1 \mathrm{~cm} ; \mathrm{b}=5 \mathrm{~mm} ; \mathrm{c}, \mathrm{d}=0.1 \mathrm{~mm}$. 

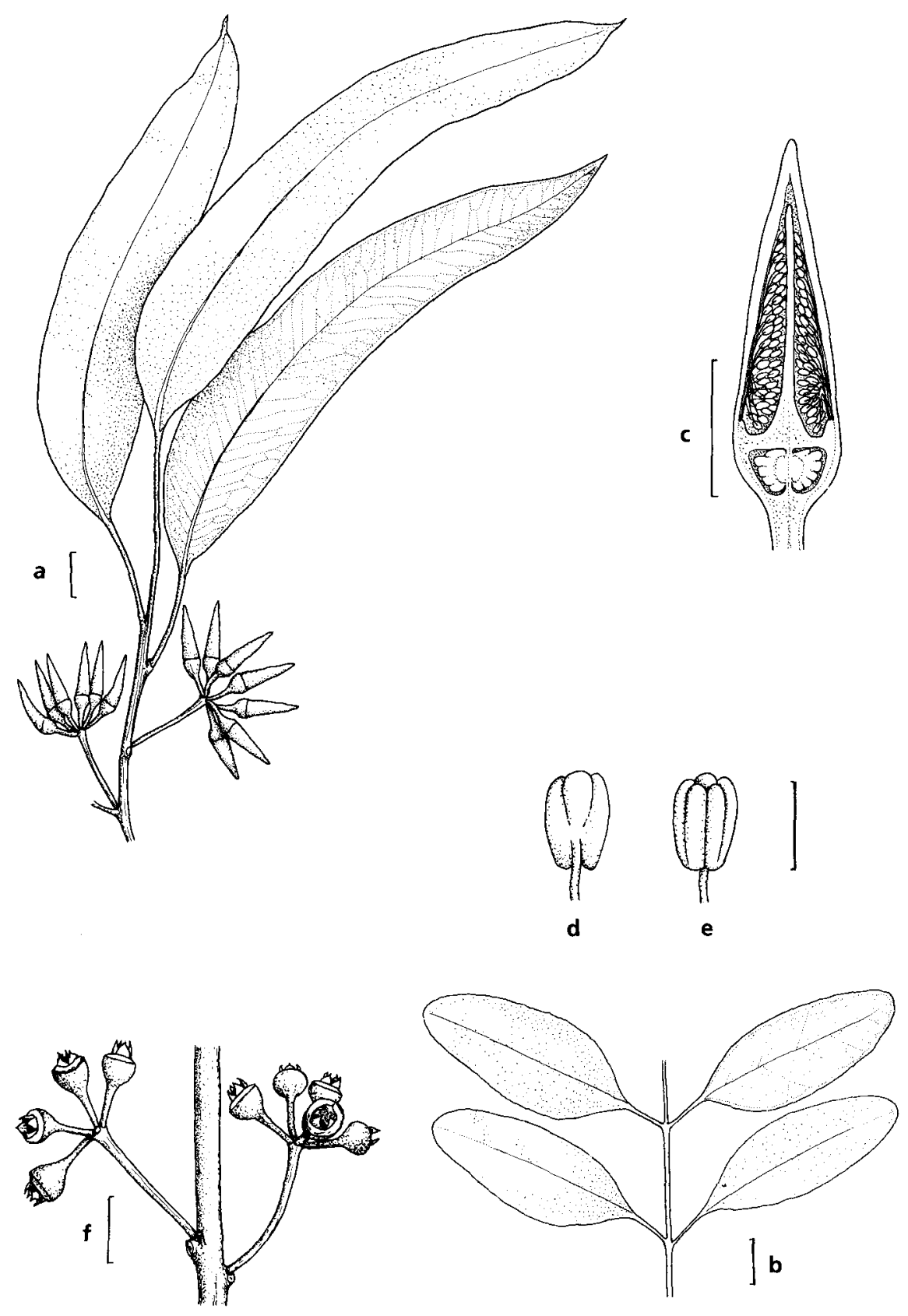

Figure 3. E. disclusa, a, adult leaves and buds. $\mathbf{b}$, juvenile leaves. $\mathbf{c}$, median section of bud. $\mathbf{d}, \mathbf{e}$, anthers. f, fruits (all from Brooker 3776). Scale bar: a, b, $f=1 \mathrm{~cm} ; \mathrm{c}=5 \mathrm{~mm} ; \mathrm{d}, \mathrm{e}=0.5 \mathrm{~mm}$. 
ECOLOGY: Restricted to rocky sandstone areas, probably with somewhat impeded drainage, at elevations of $600-900 \mathrm{~m}$, associated with E. umbra R. Baker or a related taxon.

The epithet is from the Latin disclusus, kept apart, referring to the wide separation of the areas of occurrence of this and species closely related to it.

CONSERVATION STATUS: 2V. Occurs in small relict populations.

SelfCted SPECIMENS (from 9 examined): QueEnSLAnd: campsite on Mimosa Creek, Blackdown Tableland, Henderson 674, Andrews \& Sharpe, 18 Apr 1971 (BRI, NSW); Mimosa Creek, Blackdown Tableland, Blaxell 754 \& Johnson, 26 Nov 1972 (NSW).

\section{Eucalyptus vicina L. Johnson $\mathcal{E}$ K. Hill, sp. nov.}

Affinis E. dwyeri sed foliis juvenilibus latiores, alabastris fructibusque minoribus et calyptra rotundata distinguitur.

Type: New South Wales: North Far Western Plains: Manara Hill, L. Johnson \& D. Blaxell 431, 16 Apr 1970 (holo NSW; iso CANB, MEL).

Mallee or tree to $10 \mathrm{~m}$ high. Bark smooth, patchy white to dark grey. No pruinosity present. Juvenile leaves disjunct, broad-lanceolate to ovate, obtuse or mucronate, to $7 \mathrm{~cm}$ long, $4 \mathrm{~cm}$ wide; petioles to $12 \mathrm{~mm}$ long. Adult leaves disjunct, similifacial, narrow- to broad-lanceolate, obtuse, acute or acuminate, $7-14 \mathrm{~cm}$ long, $1.2-3.0 \mathrm{~cm}$ wide; petioles flattened, $7-14 \mathrm{~mm}$ long; lateral veins closely to moderately spaced, irregular, at $30-50^{\circ}$ to midrib; reticulum open, discontinuous; intramarginal vein continuous, distinct, $0.5-1.0 \mathrm{~mm}$ from margin. Inflorescences simple, axillary; umbellasters 7-flowered; peduncles terete or angular, 4-8 mm long; pedicels terete or ribbed, 1-3 $\mathrm{mm}$ long. Mature buds ovoid, 6-8 $\mathrm{mm}$ long, 3-4 mm diam. Calyptra double, outer shed early, inner broadly conical or hemispherical, 1-1.5 times as long as hypanthium. Stamens all fertile; filaments irregularly erect in bud; anthers elliptical, dorsifixed, versatile, dehiscing by parallel slits. Fruits cup-shaped to hemispherical, 3-4-locular, 4-5 mm long, 5-6 mm diam.; calyptra scar flat, continuous with stemonophore, the two less than $0.5 \mathrm{~mm}$ wide together; disc flat or slightly depressed or domed, c. $1 \mathrm{~mm}$ wide; valves broadly triangular, obtuse, strongly exserted at $45-90^{\circ}$. Seeds semi-glossy,

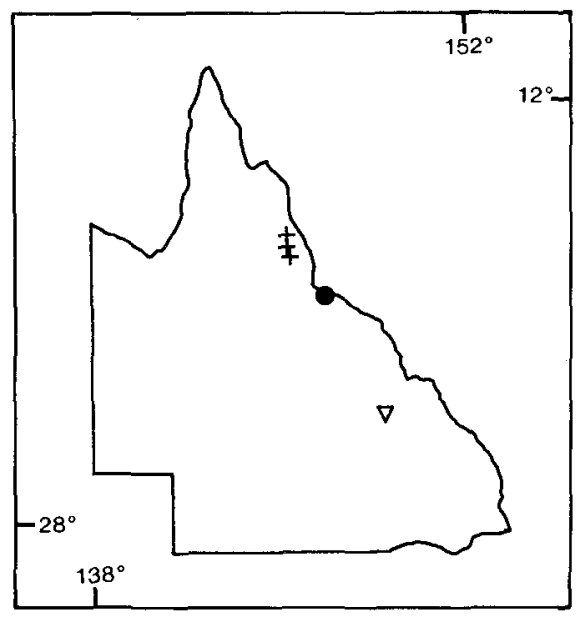

Figure 4. Distribution of E. disclusa $(\nabla)$, E. lockyeri $(+)$ and E. paedoglauca $(\bullet)$. 


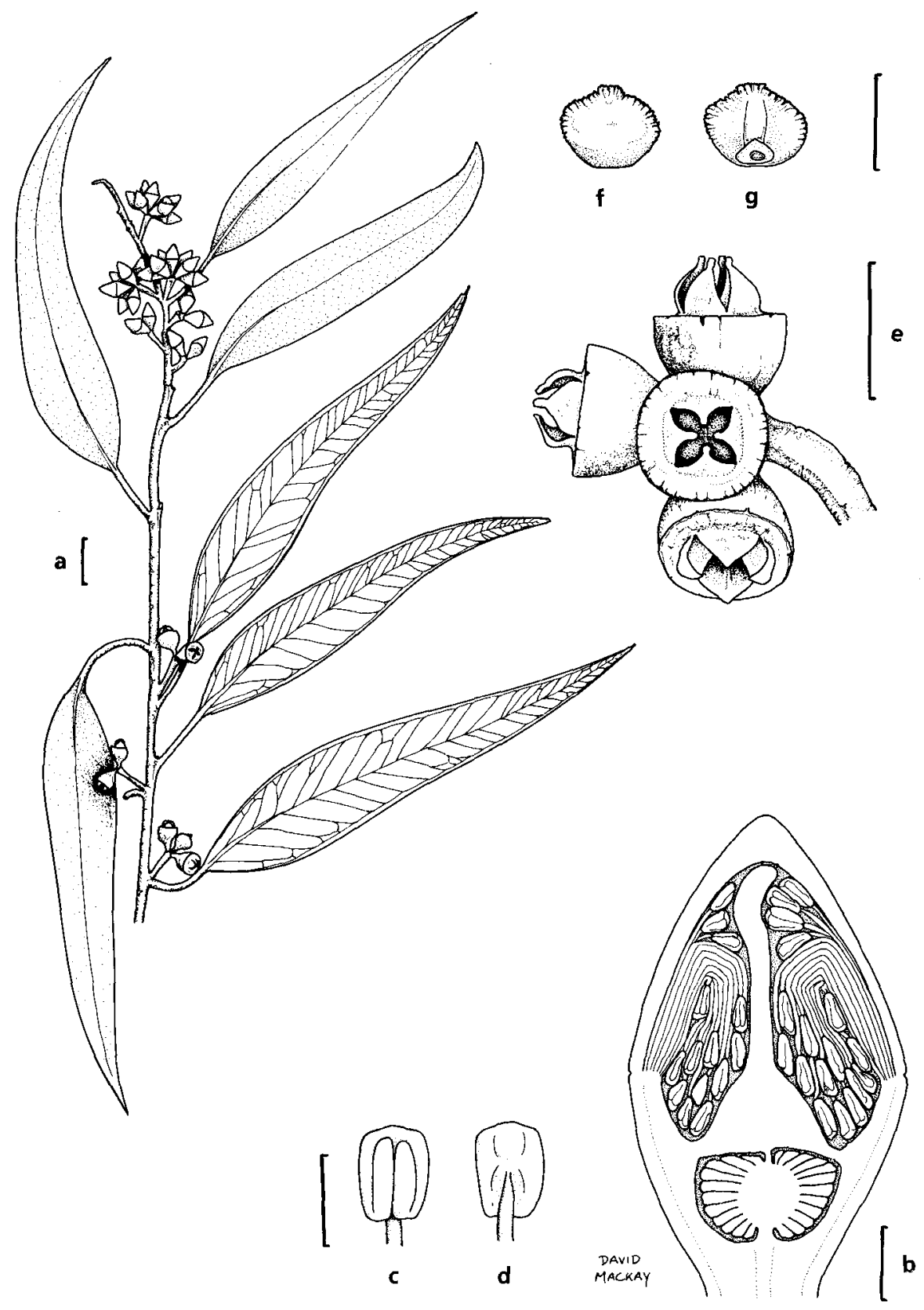

Figure 5. E. vicina. $\mathbf{a}$, adult leaves with buds and fruit. $\mathbf{b}$, median section of bud. $\mathbf{c}, \mathbf{d}$, anther. e, fruit. f, g, seed (a, e, f, g from Johnson, 25 May 1969, c, d, e from Johnson \& Blaxell 431). Scale bar: $a=1 \mathrm{~cm} ; \mathrm{e}=5 \mathrm{~mm} ; \mathrm{b}, \mathrm{c}, \mathrm{d}, \mathrm{f}, \mathrm{g}=0.1 \mathrm{~mm}$ 
charcoal-black, angular, cuboid or pyramidal with dentate fringes, deeply loosely reticulate, c. $1 \mathrm{~mm}$ long; hilum ventral; chaff red-brown, semi-glossy. Figure 5.

E. vicina is distinguished from $E$. dwyeri Maiden \& Blakely by the broader juvenile leaves (to broad-lanceolate in the latter), the smaller fruits (fruit to $7 \times 7 \mathrm{~mm}$ in the latter), and the rounded calyptra.

Distribution: Western New South Wales, Bourke to Lake Cargelligo, west to Mootwingee (Figure 1).

ECOLOGY: Locally abundant on siliceous residuals through the western parts of New South Wales.

The epithet is from the Latin vicinus, neighbouring or closely resembling, from its resemblance to $E$. dwyeri Maiden \& Blakely and other small red gums.

CONSERVATION STATUS: not considered to be at risk.

SELECTED SPECIMENS (from 30 examined): NeW SOUTH WALES: North Western Plains: Gunderbooka Range, Blaxell 572, 523, 524, 3 Nov 1971 (NSW); Mt Buckwarron, Fatchen, 26 Jul 1985 (NSW); 3.7 $\mathrm{km} \mathrm{N}$ of Mt Grenfell, Crisp 7888, 17 Dec 1986 (CBG, NSW). South Western Plains: Merrimerriwa Range, Slee 745 \& Holgate, 1 Sep 1982 (CANB, NSW); Round Hill, Hill 112 \& Johnson, 11 Oct 1983 (NSW); $3 \mathrm{~km} \mathrm{~W}$ of Roto, Pickard 1926, 16 Mar 1973 (NSW); $16 \mathrm{~km}$ WSW of Lake Cargelligo, B.G. Briggs 8028 \& Johnson, 17 Apr 1987 (NSW, CANB, MEL, PERTH). North Far Western Plains: Mootwingee Historic Site, Johnson, 24 May 1969 (NSW).

\section{Eucalyptus lockyeri Blaxell \& K. Hill, sp. nov.}

$\mathrm{Ab}$ E. exserta distinguitur: discus minor elevatus, folia juvenilia late lanceolata vel ovata, folia adulta late lanceolata vel anguste ovata, folia alabastra et fructus valde glauca.

TYPE: QuEENSLAND: Camping reserve near 'Evelyn' homestead, NW of Ravenshoe, D.F. Blaxell 1611, 3 Jun 1978 (holo NSW).

Tree to $9 \mathrm{~m}$ high, often with short irregular bole and twisted branches. Bark persistent, dark grey, subfibrous or flaky on trunk and base of lower limbs; smooth, regularly shed, orange-brown, pinkish grey or grey on limbs. Small limbs and twigs often strongly glaucous. Seedling leaves shortly petiolate, oblong-obovate, opposite for few nodes. Juvenile leaves disjunct, petiolate, oblong or ovate, rounded, mucronate, $6-8 \mathrm{~cm}$ long, 3.5-4 cm wide, usually strongly glaucous. Adult leaves disjunct, ovate-lanceolate or lanceolate, acute or acuminate, $9-15 \mathrm{~cm}$ long, $2.5-5 \mathrm{~cm}$ wide, glaucous on new growth; petioles slightly flattened above, 12-20 mm long; lateral veins widely spaced, irregularly reticulate, at $40^{\circ}-50^{\circ}$ to midrib; intramarginal vein distinct, $1-2.5 \mathrm{~mm}$ from margin. Umbellasters axillary, 7-flowered, buds and fruits glaucous; peduncles with 2 low wings, $10-20 \mathrm{~mm}$ long; pedicels terete or shortly winged, 3-6 mm long. Mature buds 9-11 mm long, 4-5 mm diam.; calyptra evenly conical, obtuse, 2-3 times longer than hypanthium; outer calyptra scar distinct. Anthers all fertile; filaments erect and irregularly inflexed in bud; stamens ovoid, dorsifixed, versatile, dehiscing by slits. Fruits 4-5-locular, campanulate or conical, with 2-4 vertical ridges, 11-12 $\mathrm{mm}$ long, 9-13 $\mathrm{mm}$ diam.; calyptra scars and staminophore distinct, forming a narrow depressed groove at top of hypanthium; disc broad, flat or somewhat domed; valves vertically exserted, broadly triangular, acute or acuminate. Seeds dark brownish black, dull, angular, to $1 \mathrm{~mm}$ long; chaff smaller, pale brown. Figure 6 .

E. lockyeri is nearest to E. exserta F. Muell., from which it is distinguished by the less raised disc, the broad-lanceolate to ovate juvenile leaves (linear to narrow-lanceolate in the latter), the broad-lanceolate to narrow-ovate adult leaves (lanceolate in the latter) and the strongly glaucous leaves, buds and fruits. 

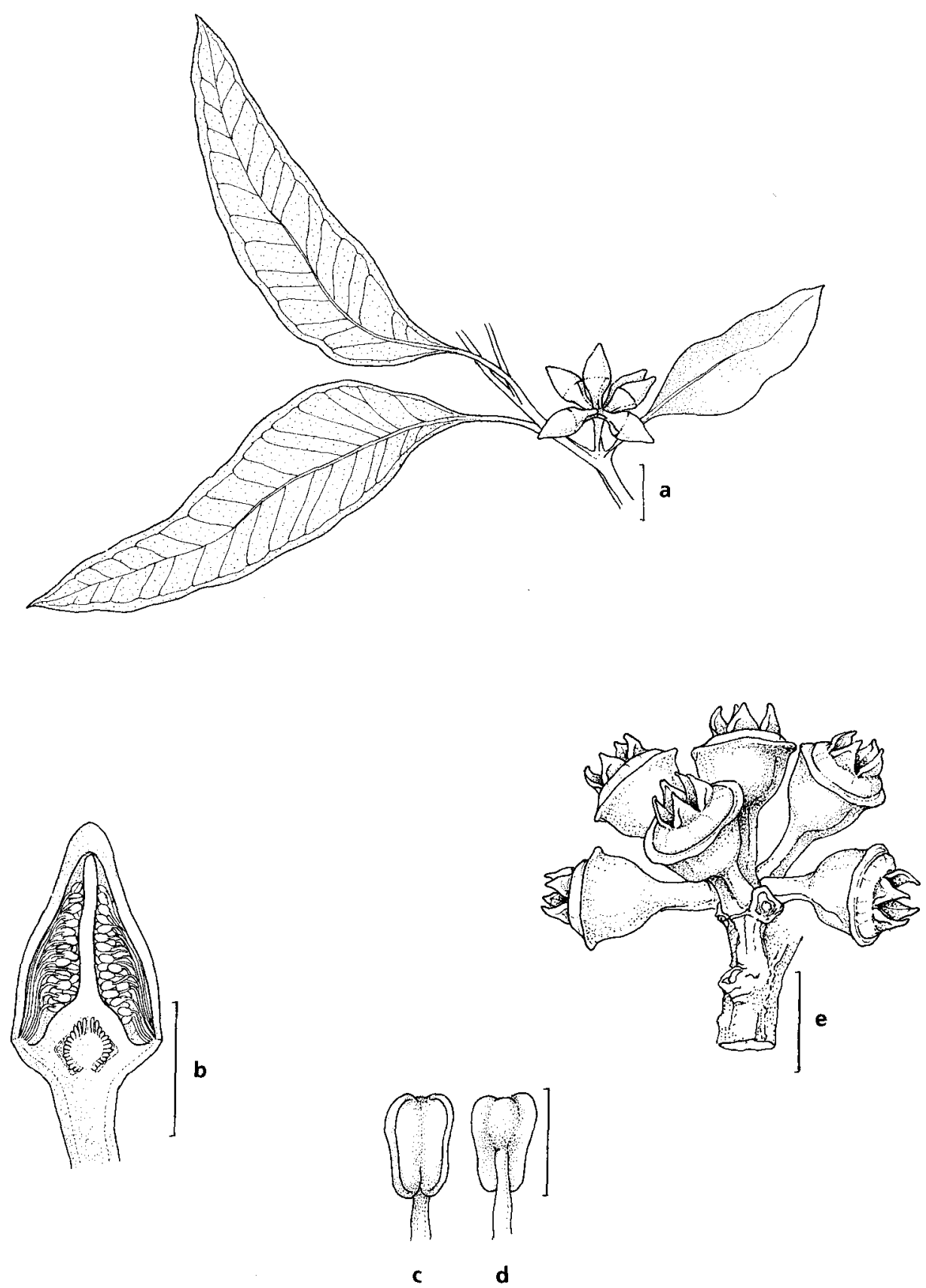

Figure 6. E. lockyeri. a, adult leaves and buds. b, median section of bud. $\mathbf{c}, \mathbf{d}$, anther. $\mathbf{e}$, fruits (a, b, c, d from R.W. Lockyer 108C; e from M.G. Lockyer 102A). Scale bar: $\mathrm{a}, \mathrm{e}=1 \mathrm{~cm} ; \mathrm{b}=5 \mathrm{~mm}$; , $\mathrm{d}=1 \mathrm{~mm}$. 
Distribution: North QueEnSLAND: Restricted to several local occurrences to the northwest of Ravenshoe (Figure 4).

ECOLOGY: This species forms small almost pure stands on poor, rocky soils derived from acid volcanics and acid granites, usually on low ridges or lower slopes of higher hills.

The epithet honours Michael Lockyer of Ravenshoe, who first drew the authors' attention to this taxon.

CONSERVATION STATUS: $3 R$. Occurs in small populations, which are generally not in reserved areas.

SeLECTED SPECIMENS (from 32 examined): QuEENSLAND: West of Herberton, crest of Great Dividing Range, Blake 22102, 28 Aug 1963 (BRI, NSW); near Cairns railway line, 11 miles [17.6 km] NW of Ravenshoe, R.W. Lockyer 108 A,B,C,D, 20 Mar 1978 (NSW); near old Evelyn homestead, N of Ravenshoe,Brooker 6528, 11 Oct 1979 (CANB, BRI, NSW); Diddleluma Creek, c. 7 km NW of Ravenshoe, Blaxell 1616, 3 Jun 1978 (NSW); Robinson Creek area east of the Ravenshoe to Tumoulin road, Clarkson 2666, 11 Oct 1979 (BRI, CANB, NSW); 4 miles [9.2 km], 288 from Ravenshoe, M.G. Lockyer 102 A,B,C,D, 26 Mar 1978 (NSW).

\section{Eucalyptus parvula L. Johnson \& K. Hill, nom. nov.}

Eucalyptus parvifolia Cambage, Proc. Linn. Soc. New South Wales 34: 336 (1909); nec Newberry, Flora Amboy Clays: 112 (1895) [nec F. Muell. (1859), in syn., nom. nud.].

TYPE CITATION: 'Hab - Flat land near the head of the Kybean River'.

TYPE: New SOUTH WALES: Southern Tablelands: Kybean River, 16 miles [26 km] E of Nimmitabel, R.H. Cambage 1924, 9 Feb 1908 (lecto NSW; isolecto CANB). This specimen bears a note in Cambage's hand stating 'confined to flats' (among other details). This note links the specimen to the protologue, and it is hence selected from two Cambage collections as lectotype.

A new name is required here as the combination Eucalyptus parvifolia is preoccupied by Newberry's fossil species.

The epithet is from the Latin parvulus, little, in reference to the small leaves and the generally small size of the tree in all its parts.

Conservation Status: 2VC (Briggs \& Leigh (1988)).

\section{The E. cinerea species complex or 'superspecies'}

The following group of three species is part of a complex of six species, the $E$. cinerea group (or superspecies). Other members not discussed here are E. nova-anglica Deane \& Maiden, E. triplex L. Johnson \& K. Hill, and E. cinerea F. Muell. ex Benth.

\section{Eucalyptus cephalocarpa Blakely, Key Eucalyptus: 164 (1934).}

Type citation: 'Specimens collected by J.H. Maiden from Dandenong Mountains, Victoria, constitute the type; while specimens collected near Ringwood, Victoria (C. Walter and R.H. Cambage), may be regarded as co-types.'

TYPe: Victoria: Dandenong Mtn, J.H. Maiden, Jan 1901 (holo NSW 233111). Blakely described this as a new species, citing E. cinerea F. Muell. ex Benth. var. multiflora Maiden (below) as a synonym. 
$\equiv$ E. cinerea F. Muell. ex Benth. var. multiflora Maiden, Crit. Revis. Eucalyptus 3: 7 (1914). TYPE CITATION: Maiden cited no Type, but gave extensive notes on occurrence, mentioning 15-20 collections from the South Coast of New South Wales and eastern and central Victoria. This material represents both $E$. cephalocarpa and E. conspicua. TYPE: VICTORIA: Dandenong Mtn, J.H. Maiden, Jan 1901 (lecto NSW 233111). This specimen accords with Maiden's description, and is here designated the lectotype to fix the nomenclature as used by Blakely (above) and Chippendale (1988). We do not regard Blakely's description as a lectotypification as stated by Chippendale. This difference in interpretation entails no present or potential change of name.

$=$ E. pulverulenta Sims var. lanceolata Howitt, Proc. Austral. Assoc. Advanc. Sci. 7: 517 (1898). TYPE CITATION: 'It occurs between the Pilot range and Beechworth (F.v.M.), near the Ovens River (C.Falk), and in the Ovens district (D.Ingle). In Gippsland I have observed it near Buchan, at Providence Ponds (between the Avon and Mitchell Rivers), near Ostler's Creek, on the Walhalla Road, between Darlimurla and Mirboo North, at Monkey Creek between Sale and Port Albert, and at Moe'. TYPE: VictoriA: Moe, A.W. Howitt, 23 Apr 1898 (lecto MEL, here designated). This specimen is selected as Lectotype in order to fix the application of this name as a synonym of E. cephalocarpa, as the cited material also included material of E. alligatrix and E. conspicua. In their discussion of this taxon under the following name, Baker and Smith refer to inflorescences with more than three flowers and the lanceolate leaves, a statement applying principally to the E. cephalocarpa component. Included in E. cinerea var. multiflora by Maiden (op. cit.).

[= E. stuartiana F. Muell. ex Miq. var. cordata R. Baker \& H.G. Smith, Res. Eucalypts: 105 (1902), nom. illegit. The epithet of E. pulverulenta var. lanceolata, cited as a synonym by Baker \& Smith, should have been adopted in this position and rank.]

Mueller (1880) regarded both E. alligatrix and E. cephalocarpa as intermediates between $E$. cinerea ( $E$. pulverulenta as used by Mueller, not as to type) and E. bridgesiana R. Baker (his E. stuartiana F. Muell.).

E. cephalocarpa is distinguished within the E. cinerea group by the frequently green, lanceolate, and disjunct adult leaves and the 7-flowered inflorescences.

Distribution: Victoria, coastal drainage systems around Port Phillip Bay, east to around Moe (Figure 7).

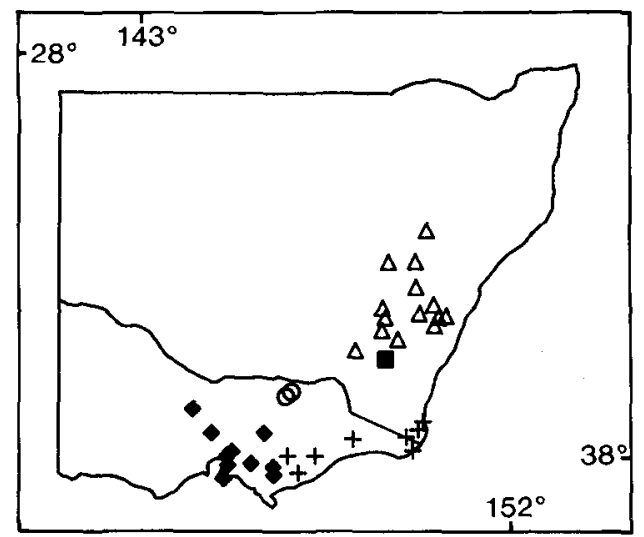

Figure 7. Distribution of E. cephalocarpa ( $\bullet)$, E. conspicua (+), E. alligatrix $(O)$, E. cinerea $(\triangle)$ and E. triplex (ם). 
Ecology: Scattered but locally frequent, usually on low-lying, often swampy sites.

CONSERVATION STATUS: Not considered to be at risk.

SElECTED SPECIMENS (from 32 examined): Victoria: 6 miles [9.6 km] SSE of Rosedale, Willis, 2 Feb 1972 (NSW, MEL 502307); $3.6 \mathrm{~km}$ W of Bunyip River bridge on Princes Hwy, Weston 426, $2 \mathrm{Jul}$ 1984 (NSW, CANB, CBG, K, MEL); 14 km E of Gembrook, Crisp 7130, 21 Jul 1983 (CBG, AD, MEL, NSW); 6 miles [9.6 km] S of Woori Yallock, Brooker 4376, 13 Feb 1974 (CANB, NSW); 1.5 $\mathrm{km}$ from Montrose towards Lilydale, Hill 1438 \& Johnson, 21 Feb 1986 (NSW); $6 \mathrm{~km}$ SW of Gisbourne, Brooker 6990, 1 Oct 1981 (CANB, MEL, NSW); Flinders, Meebold, Jan 1937 (NSW).

\section{Eucalyptus conspicua L. Johnson $\mathcal{E}$ K. Hill, sp. nov.}

$\mathrm{Ab}$ E. cinerea umbellastris 7-floris et foliis adultis lanceolatis petiolatisque distinguitur. $\mathrm{Ab}$ E. cephalocarpa foliis pruinosis et formae plus neotenicae differt.

TyPe: New SOUTh WALES: South Coast: $0.7 \mathrm{~km} \mathrm{~S}$ of Ireland Timms Road on Princes Hwy ( $37^{\circ} 16^{\prime} S 149^{\circ} 48^{\prime} \mathrm{E}$ ), K. Hill 1359 \& L. Johnson, 17 Feb 1986 (holo NSW; iso CANB, MEL, PERTH).

Tree to $10 \mathrm{~m}$, often of twisted, spreading habit. Bark persistent to smaller branches, shortly fibrous to almost stringy. Juvenile leaves opposite, sessile, orbicular, apiculate, rounded or cordate basally, glaucous, to $7 \mathrm{~cm}$ long, $6 \mathrm{~cm}$ wide. Adult leaves opposite, rarely slightly disjunct, lanceolate, sometimes ovate-lanceolate, acuminate, glaucous, 7-20 cm long, $1.5-4.0 \mathrm{~cm}$ wide; petioles $0-23 \mathrm{~mm}$ long; lateral veins at c. $30^{\circ}$ to midrib, well-spaced, anastomosing; intramarginal vein usually indistinct, sometimes evident. Umbellasters axillary, 7- or rarely 3-flowered; peduncles terete or slightly angled, 5-12 mm long; pedicels 0-2 $\mathrm{mm}$ long. Mature buds glaucous, 7-9 $\mathrm{mm}$ long, 5-6 mm diam.; hypanthium conical; calyptra rounded or conical, obtuse or acute, less than half as long as hypanthium. Stamens all fertile; filaments erect then incurved and inflexed in bud; anthers ovate, emarginate, dorsifixed, versatile, dehiscing by slits, widely opening. Fruits glaucous, conical or cup-shaped, 7-9 mm long, 6-7 mm diam., 3- or 4-locular; calyptra scar c. $0.5 \mathrm{~mm}$ wide, discontinuous with disc and hypanthium; disc 1.0-1.5 mm wide, flat or slightly raised; valves broadly triangular, flat or slightly exserted. Seeds dull, dark brown, cuboid, rounded, $1.0-1.5 \mathrm{~mm}$ long; chaff brown, linear, to $1.5 \mathrm{~mm}$ long. Figure 8 .

E. conspicua has previously been included in E. cinerea, from which it differs in the 7-flowered umbellasters and lanceolate, petiolate adult leaves. It has also been confused with E. cephalocarpa, which is also 7-flowered but is considerably less glaucous and regularly attains a fully adult foliage canopy in contrast to the neotenous adult foliage of both E. cinerea and E. conspicua.

Distribution: New South Wales: South Coast, Narrabarba southwards. Victoria: coastal regions, north and east of Mallacoota (Figure 7).

ECOLOGY: Locally frequent on poorer soils, often on hillsides with impeded drainage or on heathy flats.

Hybrids are known with E. ignorabilis L. Johnson \& K. Hill.

The epithet is from the Latin conspicuus, striking or conspicuous, referring to the distinctive overall glaucous colour of the tree, which clearly distinguishes it from all other vegetation in its habitat.

CONSERVATION STATUS: 3R. Although this species is generally in small and scattered populations, the habitat is unlikely to be under threat of development. 

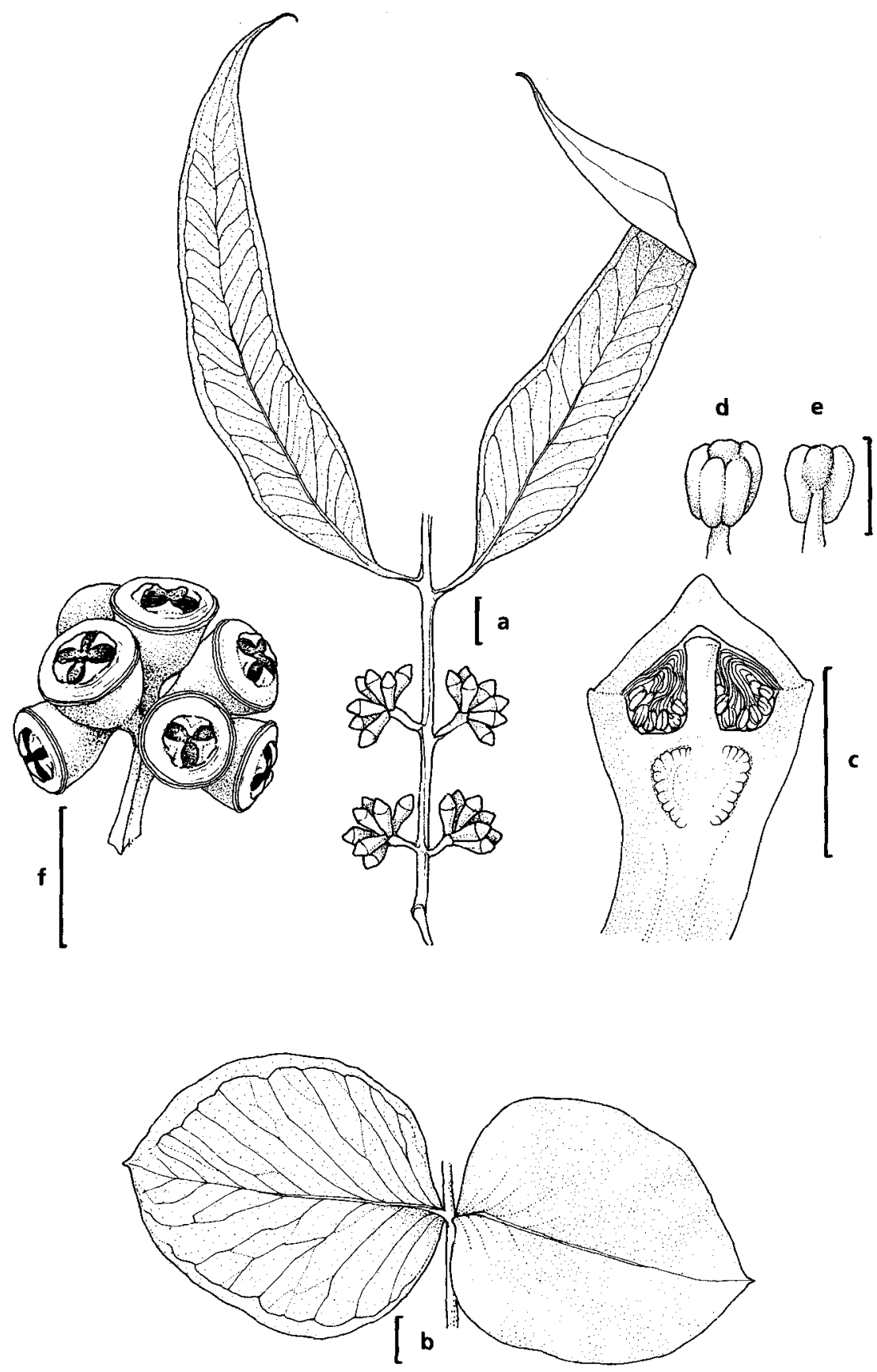

Figure 8. E. conspicua. a, adult leaves and buds. b, juvenile leaves. $c$, median section of bud. $\mathbf{d}$, e, anther. $f$, fruit (all from Wakefield 1). Scale bar: $a, b, f=1 \mathrm{~cm} ; c=5 \mathrm{~mm} ; \mathrm{d}, \mathrm{e}=0.5 \mathrm{~mm}$. 
Selected SPecimens (from 31 examined): New South Wales: South Coast: $4 \mathrm{~km} \mathrm{~S}$ of Narrabarba, Crisp 4028, Telford \& Parker, (CBG, BISH, CANB, NSW); near Timbillica, Wakefield 1, Jun 1920 (NSW). VICTORIA: 11.2 miles [18 km] E of Mt Drummer, Brooker 4413, (CANB, NSW); $6.9 \mathrm{~km}$ from Monument Road on Tara Link Road, Hill 1385 \& Johnson, 18 Feb 1986 (NSW, CANB, MEL, PERTH); 18 km E of Stratford on hwy, Hill 1396 \& Johnson, 18 Feb 1986 (NSW, CANB, MEL, PERTH); $5.1 \mathrm{~km} \mathrm{~W}$ of Seaton, Hill 1404 \& Johnson, 19 Feb 1986 (NSW, CANB, MEL, PERTH).

\section{Eucalyptus alligatrix L. Johnson \& K. Hill, sp. nov.}

$\mathrm{Ab}$ E. cinerea et E. cephalocarpa combinatione umbellastrarum triflorarum et foliorum lanceolatorum saepe disjunctorum distinguitur.

TYPE: VICTORIA: Big River, near junction with Taponga River, SW of Jamieson, L. Johnson 7675, 24 Apr 1973 (holo NSW).

Tree to $20 \mathrm{~m}$ tall. Bark persistent to smaller branches, brown, subfibrous, branchlets more or less glaucous. Juvenile leaves opposite for many nodes, sessile, orbicular, cordate, apiculate, strongly glaucous, to $4 \mathrm{~cm}$ long, $4 \mathrm{~cm}$ wide. Adult leaves disjunct or opposite, lanceolate, sometimes ovate-lanceolate, acute or acuminate, strongly glaucous, 7-17 cm long, $1.3-3.5 \mathrm{~cm}$ wide; petioles $6-18 \mathrm{~mm}$ long, leaves occasionally sessile; venation indistinct, lateral veins at $20-45^{\circ}$ to midrib, well-spaced, anastomosing; intramarginal vein sometimes distinct, 1-2 $\mathrm{mm}$ from margin. Umbellasters axillary, 3-flowered; peduncles terete or slightly flattened, 4-6 mm long. Buds and fruit sessile. Mature buds strongly glaucous, 6-8 cm long, c. $4 \mathrm{~mm}$ diam.; hypanthium conical; calyptra slightly shorter than hypanthium, conical, obtuse. Stamens all fertile; filaments initially erect then inflexed in bud; anthers ovate, emarginate, dorsifixed, versatile, dehiscing by slits and widely opening. Fruits cup-shaped or broadly conical, glaucous, 3- or 4- locular, 5-7 mm long, 4-6 mm diam.; calyptra scar distinct, 0.5-1.0 mm wide, continuous with hypanthium; disc c. $1 \mathrm{~mm}$ wide, flat or slightly raised; valves prominently exserted, broadly triangular. Seeds dull, very dark brown, cuboid, to $1 \mathrm{~mm}$ long; chaff similar, smaller and thinner. Figure 9.

E. alligatrix has previously been recognised as an intermediate taxon between E. cinerea and E. cephalocarpa, from both of which it is distinguished by the combination of the 3-flowered umbellasters and the lanceolate, often disjunct adult leaves. The populations are disjunct and clearly distinguishable (E. cinerea does not occur in Victoria).

DistRIBUTION: VictoRIA: A small area between Beechworth and the Ovens River (Figure 7).

ECOLOGY: Locally frequent on lower slopes of valleys, with E. robertsonii Blakely.

The epithet is from the Latin, alligatrix, she who binds together, referring to the intermediate position of this taxon, forming a link between $E$. cinerea and E. cephalocarpa. There is no etymological connection between this Latin word (of which the masculine equivalent is alligator) and the name of certain crocodilians. The stress is on the ' $a$ ' as in 'matrix'.

CONSERVATION STATUS: 2V. Most populations are on agricultural land or road verges, with no guarantee of continued preservation. The habitat is on agriculturally useful land, and considerable areas of this taxon have already probably been cleared.

Selected specimens (from 14 examined): Victoria: $7.2 \mathrm{~km}$ from Beechworth towards Yackandandah, Hill 1431 E Johnson, 20 Feb 1986 (NSW, CANB, MEL, PERTH; 8 km from Beechworth towards Chiltern, Crisp 7101, 27 Feb 1983 (CBG, MEL, NSW); Ovens River, Falx, 1879 (MEL, NSW). 


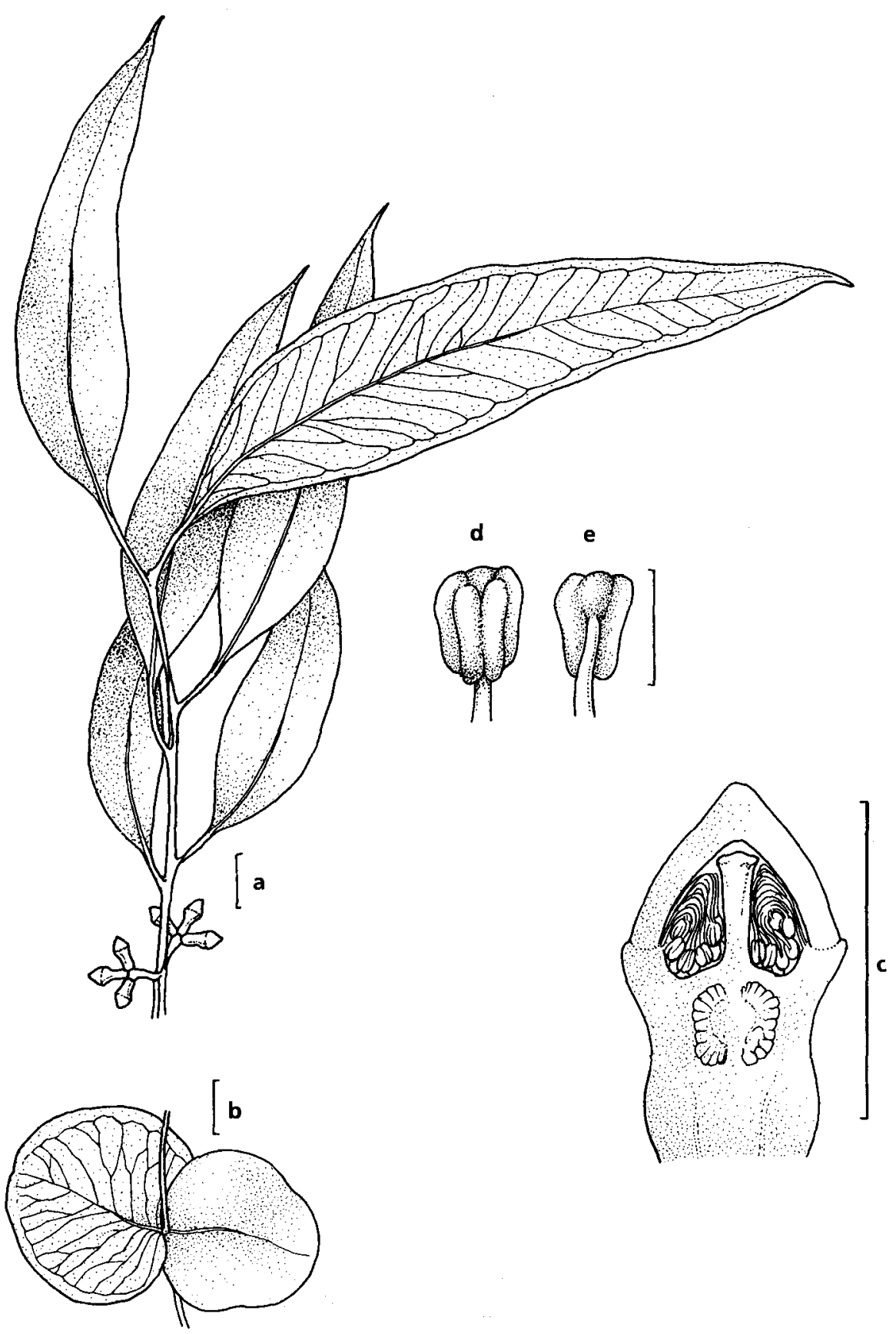

Figure 9. E. alligatrix. a, adult leaves and buds. b, juvenile leaves. c, median section of bud. d, e, anther (all from Johnson 7675). Scale bar: $\mathrm{a}, \mathrm{b}=1 \mathrm{~cm} ; \mathrm{c}=5 \mathrm{~mm}$;, $\mathrm{e}=0.5 \mathrm{~mm}$ 
9. Eucalyptus rubida Deane \& Maiden, Proc. Linn. Soc. New South Wales 24: 456 (1899).

TYPE CITATION: None cited. Notes on the range of the species mention 'Mt Kosciusko, Jindabyne, Adaminaby, Delegate to Bombala and Cooma, Michelago, Queanbeyan; northerly nearly as far as Moss Vale, Westerly as far as Sunny Corner and the tributaries of the Turon. Extends also to Victoria and South Australia (St. Vincent's Gulf).'

TYPE: New SOUTH WALES: Southern Tablelands: Jindabyne, J.H. Maiden, 1.1898 (lecto NSW, 2 sheets). Designated by Maiden (Crit. Revis. Eucalyptus 3: 123 (1916)).

Four subspecies may be recognised on the basis of systematic regional variations.

Key to the subspecies

1 Umbellasters 3-flowered

2 Juvenile leaves orbicular; trunk smooth to base

3 Juvenile leaves mostly $<4 \mathrm{~cm}$ diam.; coppice shoots terete

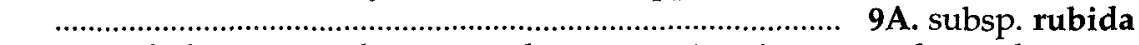

$3^{*}$ Juvenile leaves mostly $>5 \mathrm{~cm}$ diam.; coppice shoots quadrangular

9B. subsp. canobolensis

2* Juvenile leaves elliptical; trunk usually with a short, thick black stocking 9C. subsp. barbigerorum

1* Umbellasters 7-flowered

9D. subsp. septemflora

9A. Eucalyptus rubida Deane $\mathcal{E}$ Maiden subsp. rubida

$\equiv$ E. gunnii Hook. f. var. rubida (Deane \& Maiden) Maiden, Proc. Linn. Soc. New South Wales 26: 577 (1901).

[E. granularis Sieber ex Benth., Fl. Austral. 3: 240 (1867), in syn., nom. nud.]

[E. viminalis Labill. var. microcarpa F. Muell. ex Maiden, Crit. Revis. Eucalyptus 3: 112 (1916), in syn., nom. nud.]

[E. fabrorum Behr ex Maiden, Crit. Revis. Eucalyptus 3: 112 (1916), in syn., nom. nud; in part.]

This taxon was included in E. viminalis prior to Deane \& Maiden's circumscription.

Bark smooth to base. Adult and juvenile leaves, buds and fruits small. Juvenile leaves orbicular.

Intergrading populations with $E$. dalrympleana Maiden subsp. dalrympleana are scattered through southern N.S.W. and Victoria, and hybrids are recorded with E. aggregata Deane \& Maiden, E. aromaphloia Pryor \& Willis, E. corticosa and E. cinerea.

CONSERVATION STATUS: not considered to be at risk.

9B. Eucalyptus rubida Deane \& Maiden subsp. canobolensis L. Johnson \& K. Hill, subsp. nov.

Ab subspecie rubida foliis adultis juvenilibusque majoribus, alabastris fructibusque majoribus, et habitu minore differt.

TyPe: New South Wales: Central Tablelands: Mt Canobolas, Orange, J.L. Boorman, Jan 1908 (holo NSW).

Tree to $10 \mathrm{~m}$ tall, of spreading form. Bark smooth to base, white, shedding in ribbons. Twigs, leaves and inflorescences strongly glaucous when young. Juvenile leaves opposite for many nodes, broad-ovate to orbicular, sessile, apically rounded, sometimes shortly apiculate, to $11 \mathrm{~cm}$ long, $7 \mathrm{~cm}$ wide; juvenile shoots 4 -angled. Adult leaves 
disjunct, lanceolate, $10-16 \mathrm{~cm}$ long, $1.5-3.3 \mathrm{~cm}$ wide; petioles $12-35 \mathrm{~mm}$ long; lateral veins well-spaced, anastomosing, at c. $45^{\circ}$ to midrib; intramarginal vein distinct, 1-2 $\mathrm{mm}$ from margin. Umbellasters axillary, 3-flowered; peduncles distinctly flattened, 6-9 mm long; buds and fruits sessile. Mature buds oval, 5-7 $\mathrm{mm}$ long, 3-4 mm diam.; calyptra double, outer shedding early, inner obtuse, slightly shorter than hypanthium. Fruit 3-4-locular, cup-shaped, 7-9 mm long, 6-8 mm diam.; disc c. $2 \mathrm{~mm}$ wide, domed; valves exserted, broadly triangular, obtuse, angled inward at $\mathrm{c}$. $60^{\circ}$ to vertical.

Subspecies canobolensis differs from subsp. rubida in the larger adult and juvenile leaves, the larger buds and fruits, and the smaller overall tree size. The two subspecies intergrade on the lower slopes of Mt Canobolas, and only subsp. rubida occurs elsewhere in the district.

Distribution: New South Wales: Central Tablelands, known only from the summit and higher slopes of Mt Canobolas, near Orange.

ECOLOG: Locally abundant with Eucalyptus pauciflora Sieber ex Sprengel in subalpine woodland with Poa understorey, at altitudes above $1100 \mathrm{~m}$.

The epithet canobolensis is derived from that of Mt Canobolas, which is the only known habitat of the subspecies. The spelling is deliberate, and a 'correction' would be both contrary to the Code and very disagreeable in a Latin context.

CONSERVATION STATUS: 2VC. Although parts of the only known population are reserved, the entire area is subject to disturbance and frequent wildfires, both of which pose a considerable threat to the continuing viability of the population.

Selected specimens (from 10 examined): New South Wales: Central Tablelands: near top of Mt Canobolas, Garden, 1 Oct 1949 (NSW); Mt Canobolas, Johnson, 15 Aug 1953 (NSW 24996); summit of Mt Canobolas, Brooker 3061, 17 May 1971 (CANB, NSW).

9C. Eucalyptus rubida Deane $\mathcal{E}$ Maiden subsp. barbigerorum L. Johnson $\mathcal{E}$ K. Hill, subsp. nov.

Ab subspecie rubida foliis juvenilibus ellipticis et tibiali crasso nigro distincto corticis persistens partem inferam trunci investente differt.

TYPE: New South WALes: Northern Tablelands: $14.1 \mathrm{~km}$ from Wandsworth towards Tingha, K. Hill 2117, 29 Aug 1986 (holo NSW, iso BRI, CANB, PERTH).

Tree to $15 \mathrm{~m}$ tall. Bark smooth, white, shedding in ribbons, with a thick dark grey or black stocking to 1-2 $\mathrm{m}$ on the lower trunk. Twigs, leaves and inflorescences glaucous when young. Juvenile leaves opposite for many nodes, ovate to elliptical, sessile, usually shortly apiculate, to $14 \mathrm{~cm}$ long, $8 \mathrm{~cm}$ wide; juvenile shoots terete. Adult leaves disjunct, lanceolate, $10-22 \mathrm{~cm}$ long, $1.3-3.3 \mathrm{~cm}$ wide; petioles $12-33 \mathrm{~mm}$ long; lateral veins well-spaced, anastomosing, at c. $45^{\circ}$ to midrib; intramarginal vein distinct, 1-2 mm from margin. Umbellasters axillary, 3-flowered; peduncles terete, 5-8 $\mathrm{mm}$ long; buds and fruit sessile. Mature buds oval, 5-7 mm long, 3-4 mm diam.; calyptra double, outer shedding early, inner obtuse, slightly shorter than hypanthium. Fruits 3-4-locular, cup-shaped, 7-9 $\mathrm{mm}$ long, 6-8 $\mathrm{mm}$ diam.; disc c. $2 \mathrm{~mm}$ wide, domed; valves broadly triangular, obtuse.

Subspecies barbigerorum differs from subsp. rubida in the elliptical juvenile leaves, and the distinct thick, black stocking of persistent bark on the lower trunk.

Distribution: New South Wales: Northern Tablelands, known from scattered populations to the west of Glen Innes and Guyra, and in the Moonbi Ranges between Woolbrook and Nundle. 
ECOLOGY: Locally abundant or dominanting in grassy woodland on deep, fertile clayloam soils, often with E. melliodora Cunn. ex Schauer, E. viminalis Labill., E. dalrympleana Maiden subsp. heptantha L. Johnson and Angophora floribunda (Smith) Sweet.

Considerable intergradation occurs with $E$. dalrympleana subsp. heptantha in country north-west of Guyra and north of Glen Innes.

The epithet is from the Latin barbigerorum, 'of the beard-bearing ones'; in allusion to the occurrence of this taxon in 'the land of the beardies', referring to the bearded pioneers of European settlement in the area.

CONSERVATION STATUS: $3 \mathrm{~V}$. Most populations are on agricultural land or road verges, with no guarantee of continued preservation. The habitat is on agriculturally valuable land, and considerable areas of this taxon have undoubtedly already been cleared.

Selected SPECimens (from 12 examined): New SOUtH WALEs: Northern Tablelands: $8.6 \mathrm{~km}$ from Wandsworth towards Tingha, Hill 2118, 29 Aug1986 (BRI, CANB, NSW, PERTH); $20.1 \mathrm{~km}$ E Tingha on Guyra road, Hill 1293, 1294 \& Johnson, 11 Sep 1985 (NSW); $12.1 \mathrm{~km}$ from Glen Innes on Inverell road, Hill 2758, Johnson \& Weston, 20 Oct 1987 (NSW); 20 miles [32 km] NW of Guyra, Johnston \& Chippendale 655, 656, 14 Jun 1968 (CANB, NSW); near Moredun Creek, between Tingha and Guyra, Johnson \& McGillivray 2445, 21 Sep 1966 (NSW); F.R. 45231, Parish Vernon, County Parry [about 3 km SE of Woolbrook, Moonbi Range], Simon 34, 18 July 1913 (NSW).

9D. Eucalyptus rubida Deane \& Maiden subsp. septemflora L. Johnson \& K. Hill, subsp. nov.

$\mathrm{Ab}$ subspeciebus aliis umbellastris 7-floris distinguitur.

TYPE: Victoria: $3 \mathrm{~km} \mathrm{~N}$ of Mt Beauty North on Wodonga road, K. Hill $1430 \mathcal{E}$ L. Johnson, 20 Feb 1986 (holo NSW).

Tree to $25 \mathrm{~m}$ tall. Bark smooth, white, grey and reddish, shedding in ribbons. Twigs, leaves and inflorescences glaucous when young. Juvenile leaves opposite for many nodes, orbicular, sessile, to $8 \mathrm{~cm}$ long, $8 \mathrm{~cm}$ wide; juvenile shoots terete. Adult leaves disjunct, lanceolate, 8-22 cm long, 9-25 mm wide, petioles $10-30 \mathrm{~mm}$ long; lateral veins well-spaced, anastomosing, at c. $45^{\circ}$ to midrib; intramarginal vein distinct, 1-2 $\mathrm{mm}$ from margin. Umbellasters axillary, 7-flowered; peduncles terete, 5-8 $\mathrm{mm}$ long; buds and fruit sessile, or pedicels to $2 \mathrm{~mm}$ long. Mature buds oval, 5-7 mm long, 3-4 mm diam.; calyptra double, outer shedding early, inner obtuse, slightly shorter than hypanthium. Fruits 3-4-locular, cup-shaped, 5-7 mm long, 5-8 mm diam.; disc c. $2 \mathrm{~mm}$ wide, domed; valves broadly triangular, obtuse.

Distinguished by the 7-flowered umbellasters.

Distribution: known from valleys on the north-western fall of the main divide, from the upper Tumut to the upper Kiewa valleys.

ECoLoGY: A taxon of open grassy woodlands on broad, cold flats, frequently in association with E. pauciflora.

Extensive intergradation occurs with subsp. rubida where the ranges meet.

CONSERVATION STATUS: $3 \mathrm{~V}$. Most populations were on reasonably fertile, flat and readily cleared land, and much of this taxon has been cleared for grazing.

SPeCimens eXAMINED: NeW SOUTH Wales: Southern Tablelands: no collections, presence of this taxon reported by L.D. Pryor (pers. comm.). Victoria: Tawonga, Gregson, 15 Nov 1953 (NSW); 17 miles [27 km] by road from Wodonga towards Bogong, Brooker 4357, 11 Feb 1974 (CANB, NSW). 
10. Eucalyptus ignorabilis L. Johnson $\mathcal{E} K$. Hill, sp. nov.

Species $E$. corticosae et $E$. aromaphloiae affinis sed combinatione characterum sequentium distinguitur: folia juvenilia haud glauca, petiolata, anguste elliptica vel late lanceolata.

TYPE: Victoria: $4.6 \mathrm{~km}$ W of Seaton, K. Hill 1401 \& L. Johnson, 19 Feb 1986 (holo NSW; iso CANB, MEL, PERTH).

Tree to $20 \mathrm{~m}$ tall. Bark persistent to smaller branches, thick, shortly fibrous to almost stringy, grey-brown to red-brown, smooth above, grey to grey-brown, shedding in short ribbons. Juvenile leaves opposite for many nodes, grey-green, at first sessile and lanceolate, to $5 \mathrm{~cm}$ long, $0.8 \mathrm{~cm}$ wide, quickly becoming petiolate, narrow-elliptical or broad-lanceolate, to $9 \mathrm{~cm}$ long, $5 \mathrm{~cm}$ wide. Adult leaves disjunct, lanceolate, dull greygreen, 8-18 cm long, $1.2-2.8 \mathrm{~cm}$ wide; petioles $6-18 \mathrm{~mm}$ long; lateral veins at c. $45^{\circ}$ to midrib; intramarginal vein distinct, 1-2 $\mathrm{mm}$ from margin. Umbellasters axillary, 7-flowered; peduncles terete or angular, 5-8 mm long; pedicels terete, 1-3 mm long (buds rarely sessile). Mature buds ovoid, 4-6 mm long, 2-3 mm diam.; calyptra double, outer shedding early, inner hemispherical to conical, sometimes apiculate, slightly shorter than hypanthium. Fruits mainly 3-locular, sometimes 4-locular, cup-shaped or campanulate, 4-6 mm long, 4-6 mm diam.; disc c. $1 \mathrm{~mm}$ wide, flat to raised; valves broadly triangular, obtuse, angled inwards at c. $45^{\circ}$.

This species differs from both E. corticosa L. Johnson and E. aromaphloia Pryor \& Willis in the non-glaucous, petiolate, narrow-elliptical or broad-lanceolate juvenile leaves. The former has non-glaucous, narrow-lanceolate, petiolate juveniles, while the latter has sessile, glaucous, ovate juveniles. Other as yet unnamed populations differing in other respects occur in other parts of Victoria.

Distribution: South Coast of New South Wales, south from about Narrabarba, through coastal Gippsland in Victoria, west to around Morwell (Figure 10).

ECoLocy: Sporadic and local, usually in small stands in low swampy sites along minor drainage lines, often fringing small open areas of sedgeland.

The epithet is from the Latin ignorabilis, unknown, in reference to the inclusion of this taxon in the broader concept of E. aromaphloia until now. Its recognition clarifies the distinctness of $E$. corticosa, which is now seen to be confined to the upper Cudgegong River valley east of Rylstone, N.S.W.

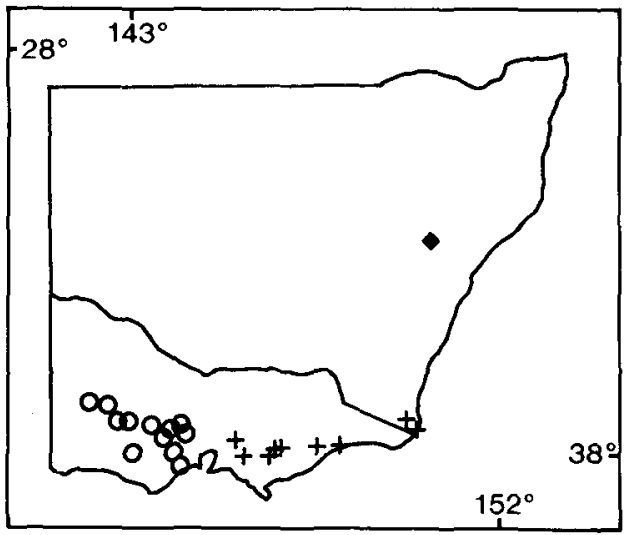

Figure 10. Distribution of E. ignorabilis $(+), E$. corticosa $(\diamond)$ and E. aromaphloia sens. lat. $(O)$. 
CONSERVATION STATUS: 3R. Although this species is generally in small and scattered populations, the habitat is unlikely to be under threat of development.

SELECTED SPECIMENS (from 19 examined): New SOUTH WALES: South Coast: junction of Imlay Creek and Wallagaraugh River, Crisp 3583, 27 Oct 1977 (CBG, CANB, NSW); Dinner Creek, 8 miles [13 $\mathrm{km}] \mathrm{N}$ of the Victorian Border, Johnson, 18 Apr 1960 (NSW 54082, CANB); Merrica River, Nadgee Nature Reserve, Olsen 3100, 3102, 28 Dec 1977 (NSW). VICtORIA: Near Cunningham [now Lakes Entrance], St John, 5 Jan 1911 (NSW); $3.6 \mathrm{~km}$ S of Princes Highway on Redcourt Lane (9 $\mathrm{km} \mathrm{W}$ of Bairnsdale), Hill 1392 \& Johnson, 18 Feb 1986 (NSW, CANB, MEL, PERTH); Walhalla, Johnson, 21 Jan 1967 (NSW); Driffield, Brooker 5129, 52305 May 1976 (CANB, NSW).

\section{Eucalyptus paedoglauca $L$. Johnson $\mathcal{E}$ D. Blaxell, sp. nov.}

$\mathrm{Ab}$ E. drepanophylla distinguitur: folia juvenilia ovata et glauca, alabastra fructusque plerumque majores.

TYPE: QUEENSLAND: Mt Stuart, $1 / 2 \mathrm{~km}$ from summit on track to radio repeater $\left(19^{\circ} 21^{\prime} \mathrm{S}\right.$, $146^{\circ} 47^{\prime} \mathrm{E}$ ), K. Hill 1167, L. Johnson \& D. Blaxell, 19 Aug 1984 (holo NSW; iso BRI, CANB, $\mathrm{K}$, PERTH).

Tree to $10 \mathrm{~m}$ tall. Bark persistent to smaller branches, hard black 'ironbark', smooth, yellowish white on branches less than $2 \mathrm{~cm}$ diam. Juvenile leaves disjunct, ovate to oblong-elliptical, glaucous, to $12 \mathrm{~cm}$ long, $7 \mathrm{~cm}$ wide; petioles thick, to c. $10 \mathrm{~mm}$ long. Adult leaves disjunct, similifacial, lanceolate, acute, 8-13 cm long, 12-30 mm wide; petioles to $17 \mathrm{~mm}$ long; lateral veins moderately spaced; intramarginal vein continuous, \pm distinct, $0.5-1.0 \mathrm{~mm}$ from margin. Inflorescences simple or compound, terminal or axillary; umbellasters 3-7-flowered; peduncles \pm angular, 4-9 $\mathrm{mm}$ long; pedicels \pm flattened, 2-4 mm long. Mature buds ovoid, c. $6 \mathrm{~mm}$ long, c. $4 \mathrm{~mm}$ diam.; calyptra hemispherical to convex-conical, broadly apiculate, slightly shorter than hypanthium. Fruits cup-shaped, 4-5-locular, c. $7 \mathrm{~mm}$ long, $6 \mathrm{~mm}$ diam.; calyptra scar flat, $\pm 0.5 \mathrm{~mm}$ wide; stemonophore flat, $\pm 0.5 \mathrm{~mm}$ wide; disc \pm vertically depressed, c. $1 \mathrm{~mm}$ wide; valves acute, basally enclosed, apically \pm vertically exserted. Figure 11.

E. paedoglauca is distinguished from E. drepanophylla F. Muell. ex Benth. by the ovate, glaucous juvenile leaves. The buds and fruits also tend to be larger in E. paedoglauca.

Distribution: At present known only from around the summit of Mt Stuart, near Townsville (Figure 4).

Ecology: Locally abundant in grassy woodland with E. exserta F. Muell. on skeletal soils over trachyte on the broad crest of a high coastal hill (elevation about $500 \mathrm{~m}$ ).

The epithet is from the Greek pais, paidos, a child or youth, and glaukos, pale blue or grey, alluding to the glaucous juvenile leaves.

CONSERVATION STATUS: 2VC. Known only from the type population.

SElECTED SPECIMENS (from 5 examined): QUEENSLAND: about $100 \mathrm{~m}$ below the summit of Mt Stuart, near Townsville, Blaxell 2074, 2075, 2076, 4 Sep 1983 (NSW); below summit of Mt Stuart, near Townsville, Brooker 8958, 30 Apr 1985 (CANB, NSW).

12. Eucalyptus caleyi Maiden, Proc. Linn. Soc. New South Wales 30: 512 (1906).

TYPE CITATION: Maiden cited seven collections in the protologue without specifying a type. He did however refer to one ('Tingha, Boorman, 6.1904') as having 'fruits less pear-shaped than the type'. He later designated 'Howell, N.S.W. (J.H.M and J.L. Boorman)' as the type (Crit. Revis. Eucalyptus 2: 99, legend to plate 56 (1910)), and had labelled this specimen 'Type'. This amounts to lectotypification.

TYPE: New SOUTH WALES: North Western Slopes: Howell, J.H. Maiden E J.L. Boorman, Aug 1905 (lecto NSW; isolecto G, K, L). 


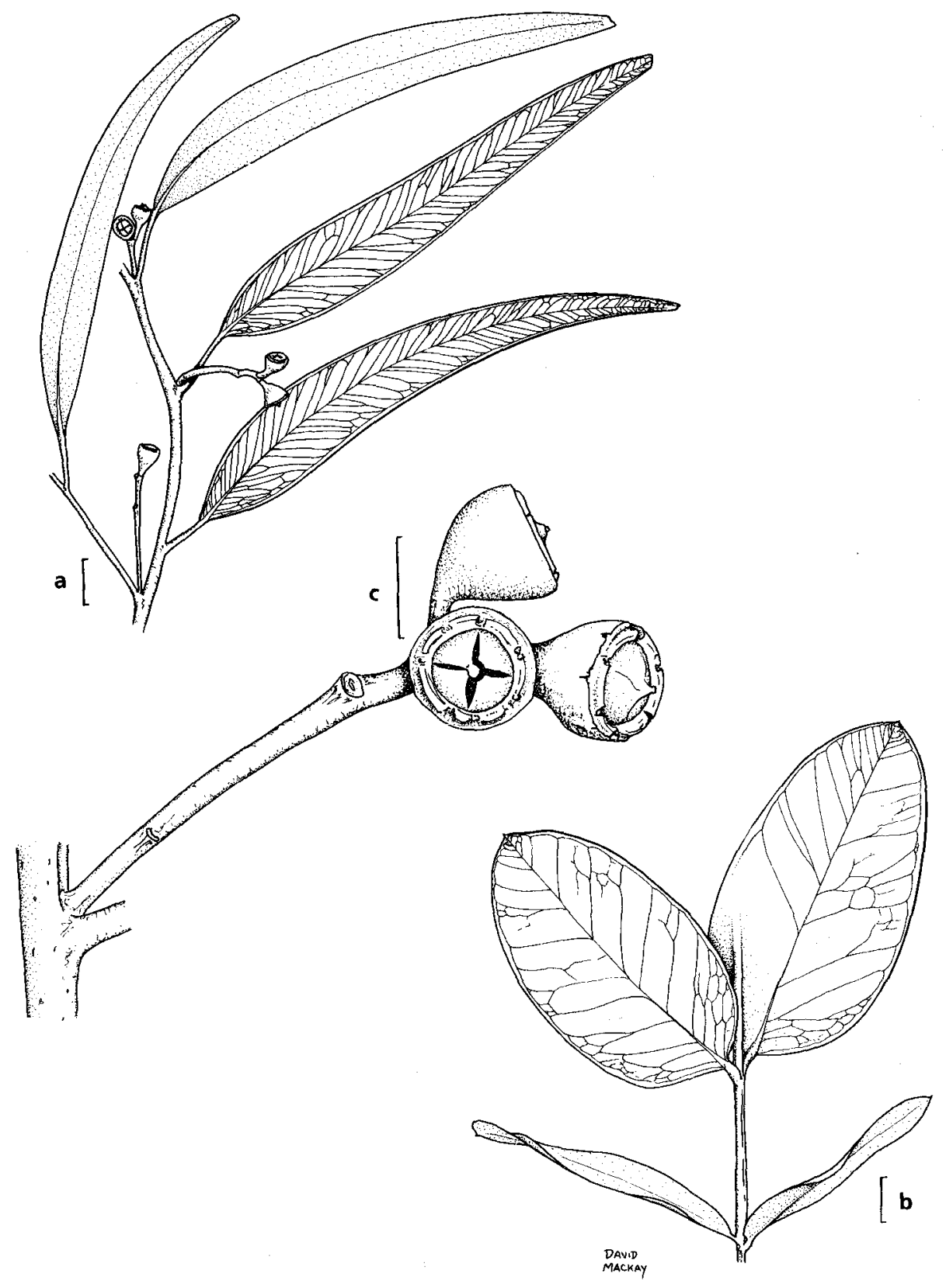

Figure 11. E. paedoglauca. a, adult leaves and fruits. b, juvenile leaves. c, fruits (all from Hill 1167, Johnson \& Blaxell). Scale bar: $a, b=1 \mathrm{~cm} ; c=5 \mathrm{~mm}$. 
Tree to $25 \mathrm{~m}$. Bark persistent throughout, ironbark. Juvenile leaves disjunct after about the 5th node, petiolate, ovate to orbicular, glaucous, to $6 \mathrm{~cm}$ long, $6 \mathrm{~cm}$ wide. Adult leaves disjunct, similifacial, glaucous, lanceolate to broad-lanceolate, $5-10 \mathrm{~cm}$ long, 15-40 mm wide; petioles 15-25 mm long. Inflorescences simple, axillary, often but not always aggregated on leafless shoots; umbellasters 7-flowered; peduncles 12-25 mm long; pedicels 5-10 mm long. Buds glaucous, rhomboid to shortly fusiform, 6-9 mm long, 4-5 mm diam.; outer calyptra shedding early; outer stamens infertile; filaments regularly inflexed; anthers adnate, cuboid, oblique to filaments, dehiscing through terminal pores. Fruits ovoid to pyriform, glaucous, $6-12 \mathrm{~mm}$ long, 5-8 mm diam.; stemonophore flat, usually persistent; disc steeply depressed. Seeds ovoid, shallowly regularly pitted, grey-brown; hilum ventral.

Two subspecies are recognised on differences in fruit size and shape.

\section{Key to the subspecies}

1 Fruits rounded 12A. subsp. caleyi

$1^{*}$ Fruits quadrangular. 12B. subsp. ovendenii

\section{A. Eucalyptus caleyi Maiden subsp. caleyi}

= Eucalyptus leucoxylon F. Muell. var. pallens Benth., Fl. Austral. 3: 210 (1867).

TYPE Citatron: 'New England, C. Stuart.' TYPE: holo K.

$\equiv$ E. sideroxylon A. Cunn. ex Woolls var. pallens (Benth.) Rehder, Cycl. Amer. Hort. 2: 552 (1900). Included in E. caleyi by Maiden in the protologue.

= E. coerulea R. Baker \& H.G. Smith, Res. Eucalypts ed. 2: 271 (1920). TYPE CITATION:

' Habitat. - Murrumbo, New South Wales.' TYPE: New South Wales: Central Tablelands: Murrumbo, R.T. Baker, Dec 1893 (lecto NSW; here designated). This specimen was annotated $E$. coerulea by Baker, and bears leaves, buds, flowers and fruit.

Chippendale (1988) erroneously cites a 1900 collection by Baker as holotype, but the application of the name is not affected. Baker and Smith at first regarded the material from this area as equivalent to Bentham's E. leucoxylon var. pallens, without seeing the type of that taxon (at the same time, they also independently made the combination E. sideroxylon var. pallens, Res. Eucalypts: 161 (1902), presumably in ignorance of Rehder's earlier publication, as cited above). They later reconsidered, regarding the two as distinct taxa when describing $E$. coerulea as a new species. Maiden included both in E. caleyi (Crit. Revis. Eucalyptus 7: 14).

Distinguished by the non-angular, smaller fruits (less than $10 \mathrm{~mm}$ long) (Figure 12).

Subsp. caleyi occurs in grassy or dry sclerophyll woodlands on shallow, often skeletal, soils on stony rises or slopes. It is restricted to the lower parts of the tablelands and the Western Slopes, from around Milmerran in Queensland south to the Goulburn River Valley in New South Wales (Figure 13). The single specimen recorded from the North Western Plains is from a characteristic Western Slopes habitat.

Hybrids are recorded with E. dealbata A. Cunn. ex Schauer, E. nubila Maiden \& Blakely, E. crebra F. Muell., E. microcarpa (Maiden) Maiden, E. albens Benth. and E. melliodora A. Cunn. ex Schauer.

CONSERVATION STATUS: not considered to be at risk.

SeleCted SPECimens (from 71 examined): New South Wales: Northern Tablelands: 26 miles [42 $\mathrm{km}$ ] W of Guyra, McKie G, 21 Sep 1927 (NSW); $40.3 \mathrm{~km} \mathrm{NW}$ of Uralla on Bundarra road, Chippendale 1250 \& Brennan, 11 Apr 1975 (CANB, NSW). North Western Slopes: $6.8 \mathrm{~km}$ W of 


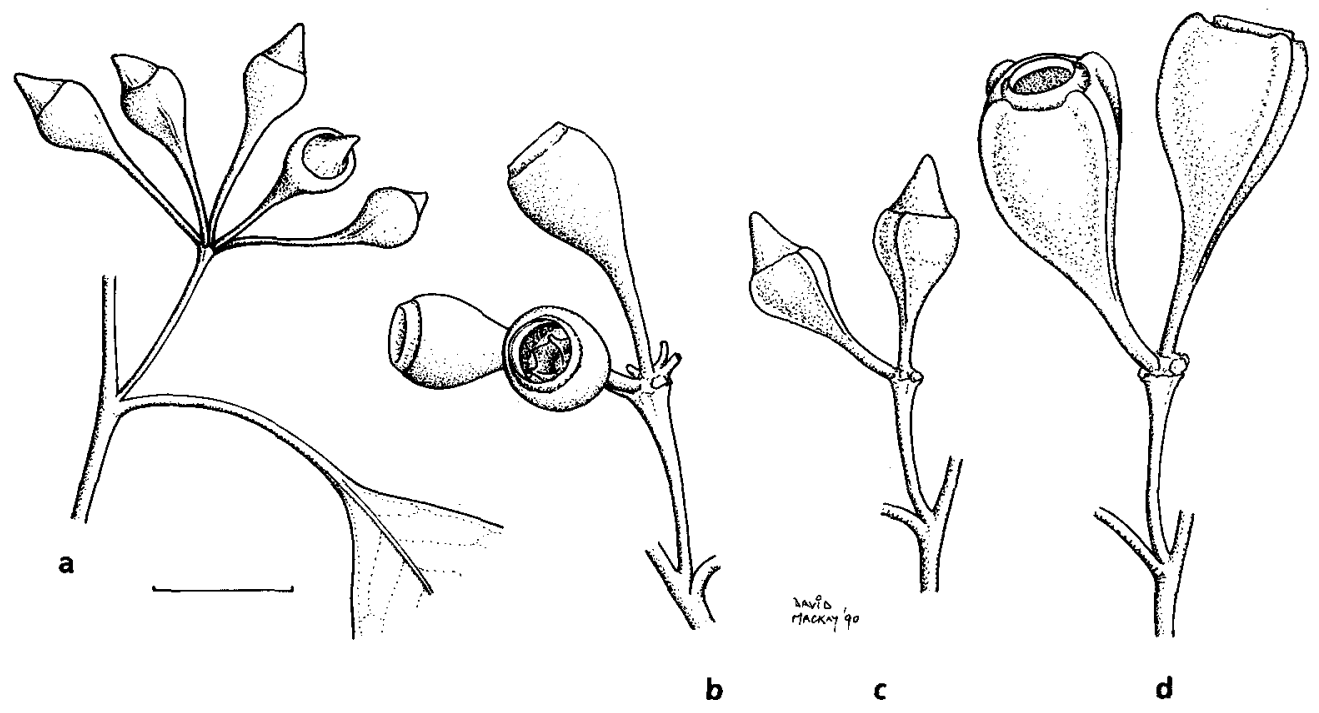

Figure 12. E. caleyi subsp. caleyi. a, buds. b, fruits (from Linton 1). E. caleyi subsp. ovendenii. c, buds. d, fruits (from Ovenden AGF 1322). Scale bar $=1 \mathrm{~cm}$.

Ashford on Graman road, Coveny 11706 \& P. Wilson, 2 Nov 1983 (NSW); c. 14 km NE of 'Keera' on Copeton Dam road, K. Wilson 2525, 22 Aug 1979 (NSW); Bundarra, Julius 1, June 1917 (NSW); Linton, Barraba district, de Beuzeville 8, 23 Jan 1913 (NSW); Attunga State Forest, Taylor 7, 3 Feb 1921 (NSW); Ogunbil, Blakely, Apr 1927 (NSW). Central Western Slopes: Baerami, Cambage 2670, 13 May 1911 (NSW); W of Wollar, Johnson \& Constable, 9 Aug 1950 (NSW 14513); 0.5 miles [0.8 $\mathrm{km}$ ] from Murrumbo towards Rylstone, Brooker 4659, 15 Nov 1974 (CANB, NSW). North Western Plains: Bebo State Forest, Bosman 5, Sep 1977 (NSW). QueEnsLAND: 'Logancrail', Gore, Bissett S 771, 7 Apr 1951 (BRI, NSW); Ballandean, White 9394, 14 Oct 1953 (BRI, NSW); Inglewood, White 6112, Nov 1922 (BRI, NSW).

12B. Eucalyptus caleyi Maiden subsp. ovendenii L. Johnson $\mathcal{E}$ K. Hill, subsp. nov.

$\mathrm{Ab}$ subspecies caleyi fructibus distincte quadrangularibus et saepe majoribus differt.

Type: New South Wales: Northern Tablelands: $25 \mathrm{~km}$ NW of Torrington, P. Ovenden AGF 1322, 30 July 1979 (holo NSW).

Distinguished by the distinctly quadrangular and often larger fruits (9-12 $\mathrm{mm}$ long) (Figure 12).

This taxon occurs within the range of subsp. caleyi, but occupies the crests of broad high ridges in a replacement pattern. Subsp. caleyi occurs on lower slopes in the same general area, and intergradation occurs in intervening areas. Subsp. ovendenii is known only from a limited area west of Tenterfield (Figure 13).

This subspecies occurs on shallow soils in open grassy woodlands with E. melliodora and E. dealbata.

CONSERVATION STATUS: 2V-.This taxon occurs over a limited area, and all known stands are on privately held property. 


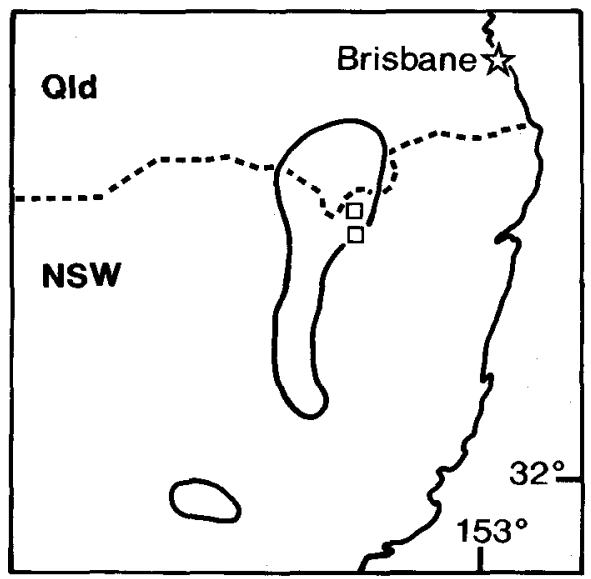

Figure 13. Distribution of E. caley subsp. caleyi (solid outline) and subsp. ovendenii ( $\square$ ).

The epithet honours Peter Ovenden, formerly of the Tenterfield District Forestry Office, an astute observer of the district's flora, who brought this taxon to our attention.

Specimens eXAmined: New SOUth WALEs: North Western Slopes: 'Moorabinda' station, Hill 817, 818, 822, Johnson \& Ovenden, 10 Apr 1984 (NSW).

\section{Eucalyptus tricarpa (L. Johnson) L. Johnson $\mathcal{E}$ K. Hill, stat. nov.}

BAsIONYM: Eucalyptus sideroxylon A. Cunn. ex Woolls subsp. tricarpa L. Johnson, Contr. New South Wales Natl. Herb. 3(3): 122 (1962).

TYPE CITATION: 'Holotype: Tilba Tilba to Wallaga Lake, N.S.W., L.A.S. Johnson 20.11.1950 (NSW 54090), flowering and fruiting.'

TYPE: holo NSW.

Distinguished from E. sideroxylon by the uniformly 3-flowered umbellasters.

Distribution: This species has two disjunct areas of occurrence, the first mainly coastal in southern N.S.W. and eastern Victoria, from the Araluen district south, and west to the Bairnsdale district. The second is in central western Victoria, from St Arnaud south to Anglesea, east to Bendigo and east of Melbourne (Figure 14). The range does not approach that of E. sideroxylon, which is mainly an inland species in N.S.W. and southern Queensland, with very limited distribution in northern central Victoria and also restricted distribution in coastal regions of N.S.W.

ECOLOGY: usually in open forest or closed woodland on shallow soils on sloping country.

The differences between this taxon and E. sideroxylon have been documented by Bramwells \& Whiffin (1984).

Hybrids are recorded with E. bosistoana F. Muell.

CONSERVATION STATUS: not considered to be at risk. 


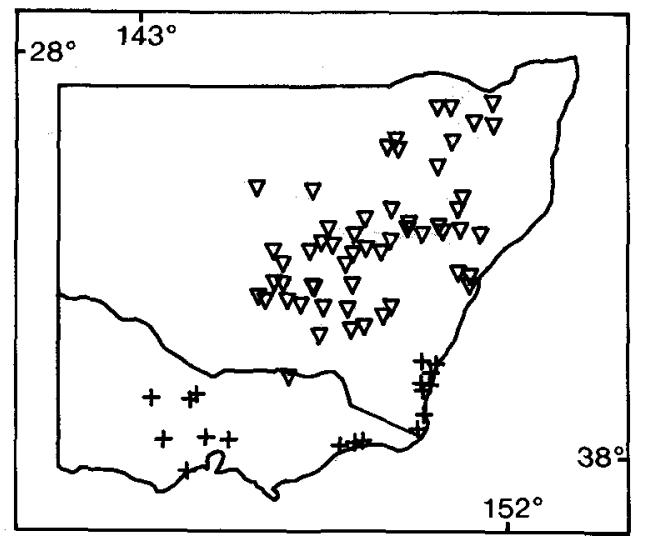

Figure 14. Distribution of E. tricarpa $(+)$ and E. sideroxylon $(\nabla)$, excluding Qld occurrences of the latter.

Selected specimens (from 38 examined): New South W Ales: South Coast: 14.8 miles [24 km] from North Araluen towards Moruya, Brooker 4943, 16 Sep 1975 (NSW, CANB); Bermagui turnoff, Princes Hwy, Turner 398, 2 Jul 1980 (NSW, CANB); Wallaga Lake, Brooker 3305, 29 Oct 1971 (NSW, CANB); 4 miles [6.4 km] N of Merimbula, Pullen 4040, 17 Mar 1964 (NSW, CANB); 0.5 miles [0.8 $\mathrm{kml}$ W of Jane Spiers Beach, Nadgee Nature Reserve, Pickard 1146, 3 Jun 1970 (NSW). VictoriA: $3.7 \mathrm{~km}$ E of St Arnaud, Hill 1628, Johnson \& Wilson, 6 Mar 1986 (NSW); $1.5 \mathrm{~km}$ from Anglesea towards Aireys Inlet, Brooker 5951, 22 Aug 1978 (CANB, MEL, NSW); $5.3 \mathrm{~km} \mathrm{~S}$ of Marlborough turnoff at Kangaroo Flat, Hill 1615, Johnson \& Wilson, 5 Mar 1986 (NSW, CANB, MEL, PERTH); Reeve Road, W of Orbost, Brooker 6817, 16 Jan 1980 (CANB, MEL, NSW); Bruthen to Double Bridges, Cambage 3675, 16 Jan 1913 (NSW).

\section{Eucalyptus prominula L. Johnson $\&$ K. Hill, sp. nov.}

Species E. tindaliae similis sed combinatione characterum sequentium distinguitur: folia adulta majora, crassiora, viridiora; alabastra majora, angularia; pedunculi longiores, crassiores, angulares; hypanthium ad summum tandem incurvum.

Type: New South Wales: Central Coast: 1 mile $[1.6 \mathrm{~km}] \mathrm{N}$ of Bucketty on Old North Road, L.A.S. Johnson, 12 May 1960 (holo NSW).

Tree to $20 \mathrm{~m}$. Bark persistent to smallest branches, grey, long-fibrous ('stringybark'). Juvenile leaves opposite or disjunct, ovate, acute, basally rounded or cordate, with moderately dense 'stellate hairs' on all surfaces, to $6 \mathrm{~cm}$ long, $3 \mathrm{~cm}$ wide; petioles 1-3 mm long. Adult leaves disjunct, glabrous, coriaceous, lanceolate to broad lanceolate, oblique, falcate, acuminate or apiculate, glossy green with a bluish sheen, $7-15$ cm long, 1.4-3.2 cm wide; petioles 13-20 mm long; lateral veins indistinct, wellspaced, at $20-30^{\circ}$ to midrib; intramarginal vein indistinct, $1-2 \mathrm{~mm}$ from margin. Umbellasters axillary, more than 7-flowered; peduncles angular, thick, 7-14 mm long; pedicels angular, 2-4 mm long. Mature buds distinctly angular, 7-9 $\mathrm{mm}$ long, 3-4 $\mathrm{mm}$ diam.; calyptra conical, acute, angular, slightly longer than hypanthium. Fruits globular, flattened, 4-locular, often with 2 or 3 low ridges, 6-7 $\mathrm{mm}$ long, 7-9 mm diam.; hypanthium globular, constricted above; calyptra scar a distinct narrow groove; disc flat to slightly raised, ultimately incurved, $1.5-2 \mathrm{~mm}$ wide; valves enclosed, ultimate fine tips usually exserted. Seeds dark brownish black, satiny, reniform, to $2 \mathrm{~mm}$ long; chaff similar, dull, brown, smaller. 
E. prominula differs from $E$. tindaliae Blakely in the larger, angular buds (4-6 mm long, 3-4 mm diam. in the latter) with longer pedicels (buds sessile or pedicels to $2 \mathrm{~mm}$ long in the latter), and in the partly exserted valves. Peduncles tend to be longer, thicker, and more strongly angular, and adult leaves tend to be larger and thicker in E. prominula.

Distribution: New South Wales: North-western Central Coast District, inland sandstone country, from the Hawkesbury River north to Broke (Figure 15).

ECOLOGY: Locally common but usually only over limited areas, on dry sandstone or shaley sandstone ridges, often in association with E. gummifera (Sol. ex Gaertn.) Hochr., E. eximia Schauer, E. piperita Smith and E. racemosa Cav.

The epithet is from the Latin prominulus, projecting a little, referring to the partially exserted valves of this species.

CONSERVATION STATUS: 2RC. This species occurs on country unlikely to be threatened by development, and several populations occur in the Yengo National Park.

SeleCted SPECIMENS (from 14 examined): New South WALES: North Coast: Pokolbin State Forest, Bailey, 22 Jun 1961 (NSW). Central Coast: $5.5 \mathrm{~km}$ due W of Paynes Crossing bridge, Hill $2785 \&$ Stanberg, 3 May 1988 (NSW, BRI, PERTH); $3.3 \mathrm{~km} \mathrm{~S}$ of Fernances Crossing on Broke - Bucketty road, Hill 1263 \& Johnson, 9 Sep 1985 (NSW, CANB, MEL); 5 miles [8 km] NE of Wisemans Ferry, Johnson, 2 Aug 1968 (NSW).

\section{Eucalyptus tenella $L$. Johnson \& $K$. Hill, sp. nov.}

Species E. sparsifoliae similis sed foliis parvis angustisque et calyptra rotundata differt.

TyPE: New SOUtH WALES: Central Tablelands: Capertee, L.A.S. Johnson, 30 Sep 1968 (holo NSW).

Tree to $15 \mathrm{~m}$ tall, often less. Bark persistent to smallest branches, grey, long-fibrous ('stringybark'). Juvenile leaves opposite or disjunct, linear to narrow-lanceolate, acute, basally rounded or tapered, with 'stellate hairs' on all surfaces, to $3 \mathrm{~cm}$ long, $0.7 \mathrm{~cm}$ wide; petioles 0-2 mm long. Adult leaves disjunct, glabrous, coriaceous, linear to narrow-lanceolate, falcate, acuminate, glossy green, $5-9 \mathrm{~cm}$ long, $0.6-1.3 \mathrm{~cm}$ wide; petioles $5-8 \mathrm{~mm}$ long; lateral veins indistinct, well-spaced, at $20-30^{\circ}$ to midrib; intramarginal vein indistinct, to $1 \mathrm{~mm}$ from margin. Umbellasters axillary, more than 7-flowered; peduncles angular, 3-8 $\mathrm{mm}$ long; pedicels $0-1 \mathrm{~mm}$ long. Mature buds ovoid, 4-5 mm long, 1.5-2 mm diam.; calyptra hemispherical to convex-conical, obtuse,

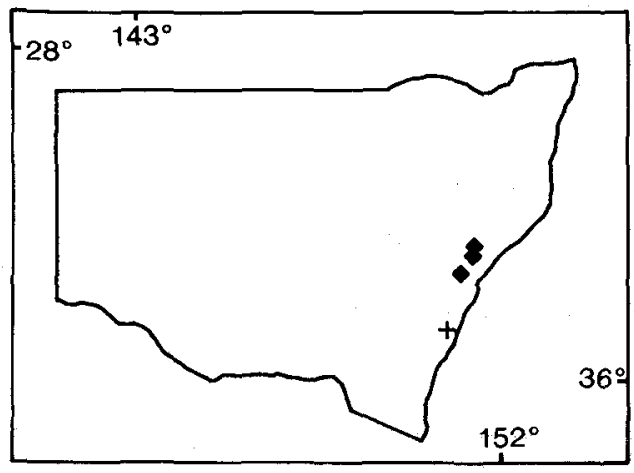

Figure 15. Distribution of E. prominula $(\bullet)$ and E. imitans $(+)$. 
shorter than hypanthium. Fruits globular, flattened, 3-4-lòcular, 4-5 mm long, 5-7 mm diam.; hypanthium globular, constricted above; calyptra scar a distinct narrow groove; disc flat to slightly raised, ultimately incurved, $0.5-1.5 \mathrm{~mm}$ wide; valves enclosed or rim-level. Seeds dark brownish black, reniform, to $1 \mathrm{~mm}$ long; chaff similar, dull, brown, smaller. Figure 16.

Distinguished from E. sparsifolia Blakely by the small, narrow leaves, the rounded calyptra and the smaller fruits (to $8 \mathrm{~mm}$ long, $8 \mathrm{~mm}$ diam. in the latter). Adult leaves are narrow-lanceolate to lanceolate and $8-12 \mathrm{~cm}$ long by $10-25 \mathrm{~mm}$ wide in E. sparsifolia, and the calyptra is acute.

Distribution: Central Tablelands of New South Wales, from near Rylstone to the Megalong Valley (Figure 17).

ECOLOGY: A component of dry sclerophyll woodlands on relatively infertile, sandy soils, usually on flat to gently rolling country with species such as E. mannifera Mudie and E. rossii R. Baker \& H.G. Smith or E. sclerophylla (Blakely) L. Johnson \& Blaxell.

Intergradation occurs with E. sparsifolia where the ranges meet.

The epithet is from the Latin tenellus, somewhat delicate, referring to the small leaves, buds and fruits.

CONSERVATION STATUS: not considered to be at risk.

Selected SPECTMENS (from 21 examined): New South Wales: Central Tablelands: $1.2 \mathrm{~km} \mathrm{~S}$ of Kandos, J.D. Briggs 229 \& Pryor, 27 Feb 1979 (CANB, NSW); head of Benjang Creek, ENE of Rylstone, Catford, Apr 1965 (NSW); Ilford, Brooker 4666, 16 Nov 1974 (CANB, NSW); $1 \mathrm{~km} \mathrm{~S}$ of Ilford, Johnson 7581, $27 \mathrm{Feb} 1973$ (NSW); 2.8 miles [4.5 km] S then 3 miles [4.8 km] E by road from Hartley Vale, Kanimbla Valley, Johnson \& McKern, 26 Sep 1966 (NSW); Pulpit Hill Ck to Chaplowe Ck, Megalong Valley, Johnson, 12 Aug 1953 (NSW 24966).

\section{Eucalyptus ralla $L$. Johnson \& $K$. Hill, sp. nov.}

$\mathrm{Ab}$ E. sparsifolia foliis adultis linearibus vel anguste lanceolatis, et ab E. tenella foliis valde longioribus, distinguitur.

Type: New South Wales: South Coast: 1 mile $[1.6 \mathrm{~km}] \mathrm{N}$ of Danjera Creek on Nowra - Yalwal road, L. Johnson, D. Blaxell \& B.G. Briggs 3139, 18 Dec 1969 (holo NSW; iso CANB, MEL).

Tree to $15 \mathrm{~m}$ tall. Bark persistent to smallest branches, grey, long-fibrous ('stringybark'). Juvenile leaves opposite or disjunct, linear to lanceolate, acute, basally rounded or cordate, with 'stellate hairs' on all surfaces, to $5 \mathrm{~cm}$ long, $1.5 \mathrm{~cm}$ wide; petioles 0-2 mm long. Adult leaves disjunct, glabrous, coriaceous, linear to narrow-lanceolate, falcate, acuminate, glossy green, $6-15 \mathrm{~cm}$ long, $0.6-1.8 \mathrm{~cm}$ wide; petioles $6-11 \mathrm{~mm}$ long; lateral veins indistinct, well-spaced, at $20-30^{\circ}$ to midrib; intramarginal vein indistinct, to $1 \mathrm{~mm}$ from margin. Umbellasters axillary, more than 7-flowered; peduncles angular, 4-9 mm long; pedicels angular, 1-2 $\mathrm{mm}$ long. Mature buds fusiform, 4-6 mm long, 1.5-2 mm diam.; calyptra conical, acute, about as long as hypanthium. Fruits globular, flattened, 3-4-locular, 4-5 mm long, 5-7 mm diam.; hypanthium globular, constricted above; calyptra scar a distinct narrow groove; disc flat to slightly raised, ultimately incurved, $0.5-1.5 \mathrm{~mm}$ wide; valves deeply enclosed. Seeds dark brownish black, reniform, to $1 \mathrm{~mm}$ long; chaff similar, dull, brown, smaller. Figure 18.

Distinguished from E. sparsifolia Blakely by the linear to narrow-lanceolate adult leaves, and smaller fruits (to $8 \mathrm{~mm}$ long, $8 \mathrm{~mm}$ diam. in the latter). The leaves are much longer than those of $E$. tenella, and buds are more pointed. 

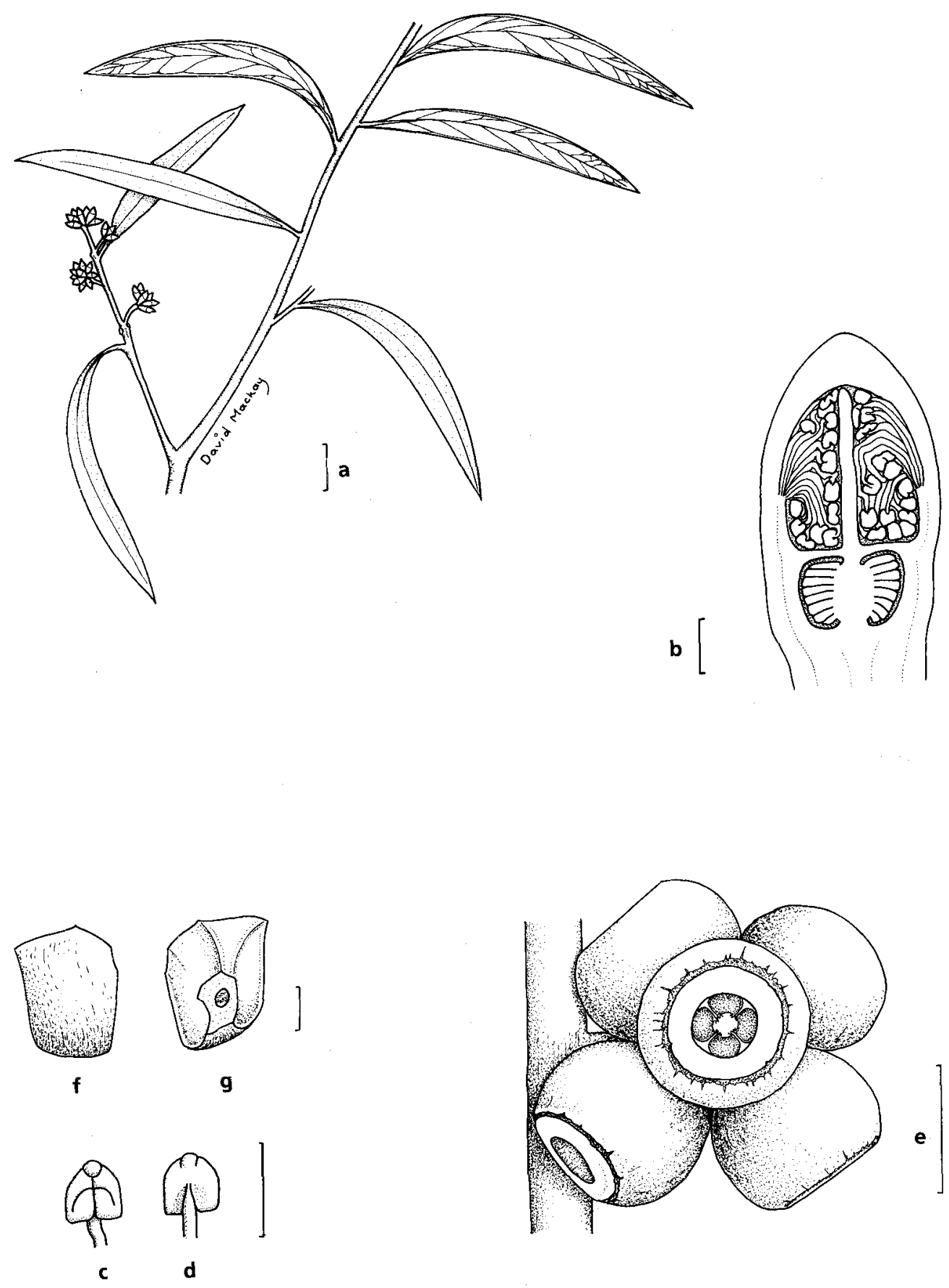

Figure 16. E. tenella. $\mathbf{a}$, adult leaves and buds. $\mathbf{b}$, median section of bud. $\mathbf{c}$, $\mathbf{d}$, anther. $\mathbf{e}$, fruit. $\mathbf{f}$, $\mathrm{g}$, seed (all from Johnson 7581). Scale bar: $\mathrm{a}=1 \mathrm{~cm} ; \mathrm{b}, \mathrm{c}, \mathrm{d}, \mathrm{f}, \mathrm{g}=0.5 \mathrm{~mm}$; e $=5 \mathrm{~mm}$. 
DistRIBUTION: Upper Nattai River to Yalwal district (Figure 17).

ECoLogr: Usually locally frequent in dry sclerophyll woodland on steep, rocky sandstone slopes.

The epithet is from the Latin rallus, slender, referring to the narrow adult and juvenile leaves.

CONSERVATION STATUS: not considered to be at risk, but further collecting is necessary to ascertain its distribution in more detail.

Selected sPecimens (from 9 examined): New South Wales: Central Tablelands: Nattai River, Olsen 2163, 2164, 29 Jun 1974 (NSW). South Coast: Yalwal, Blaxell 1602, 1603 \& Johnson, 26 May 1978 (NSW, CANB, K, MEL).

\section{Eucalyptus imitans L. Johnson \& $K$. Hill, sp. nov.}

Similis E. oblongae sed distinguitur: alabastra fructusque majores, calyptra brevior rotundataque, et folia adulta juveniliaque grossiora.

Type: New South Wales: Central Coast: $20.3 \mathrm{~km}$ from Kangaroo Valley towards Tallowa Dam, K. Hill 3620 \& R. Makinson, 7 Nov 1989 (holo NSW; iso BRI, CANB, MEL).

Tree to $10 \mathrm{~m}$ tall. Bark persistent to smallest branches, grey, long-fibrous ('stringybark'). Juvenile leaves disjunct, ovate, rounded or apiculate, basally rounded, with 'stellate hairs' on all surfaces, to $5 \mathrm{~cm}$ long, $2.5 \mathrm{~cm}$ wide; petioles $3-5 \mathrm{~mm}$ long. Adult leaves disjunct, glabrous, coriaceous, broad lanceolate to ovate, oblique, rounded or apiculate, glossy green, $5-13 \mathrm{~cm}$ long, $1.5-3.8 \mathrm{~cm}$ wide; petioles $7-12 \mathrm{n} \mathrm{m}$ long; lateral veins distinct, well-spaced, at $30-40^{\circ}$ to midrib; intramarginal vein distinct, $1-2 \mathrm{~mm}$ from margin. Umbellasters axillary, more than 7-flowered; peduncles 6-12 mm long; pedicels 0-3 $\mathrm{mm}$ long. Mature buds ovoid, 5-7 mm long, 2.5-3.5 mm diam.; calyptra hemispherical or convex-conical, often apiculate, slightly longer than hypanthium. Fruits globular, flattened, 4-locular, 5-7 mm long, 7-9 mm diam.; hypanthium globular, constricted above; calyptra scar a distinct narrow groove around hypanthium; disc flat to slightly raised, ultimately incurved, $1.5-2.5 \mathrm{~mm}$ wide; valves enclosed, ultimate fine tips sometimes exserted. Seeds dark brownish black, reniform, to $1.5 \mathrm{~mm}$ long; chaff similar, dull, brown, smaller. Figure 19.

Distinguished from E. oblonga DC. by the larger buds and fruits (to $7 \mathrm{~mm}$ diam. in the latter), the shorter and more rounded calyptra, and the generally coarser adult and juvenile foliage.

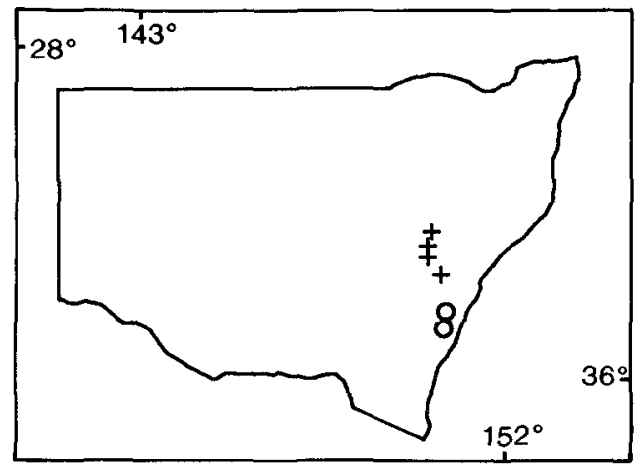

Figure 17. Distribution of E. tenella $(+)$ and E. ralla $(O)$. 

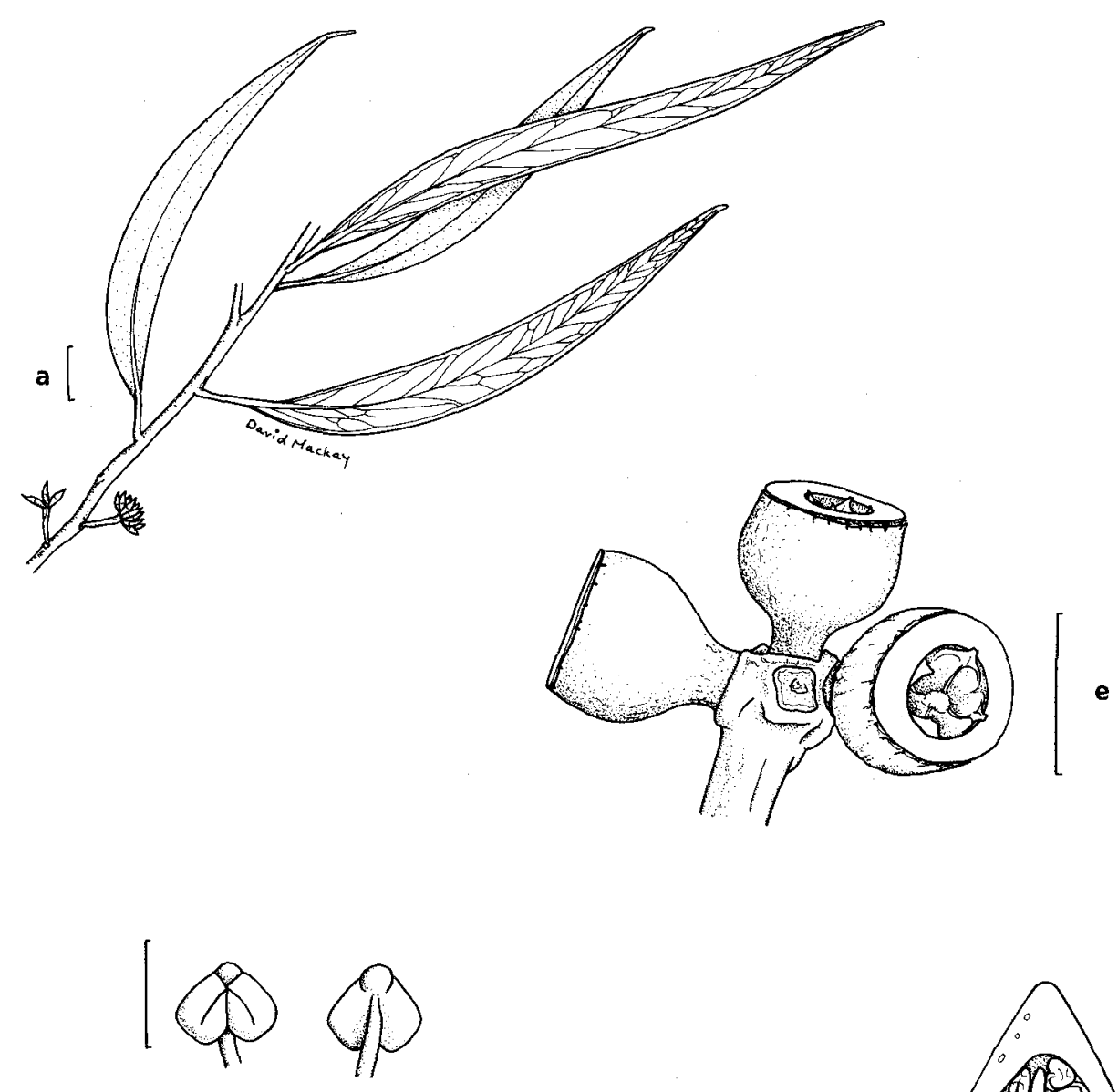

c

d
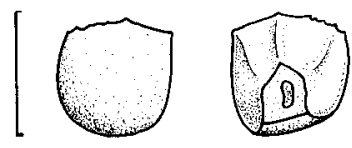

f

g

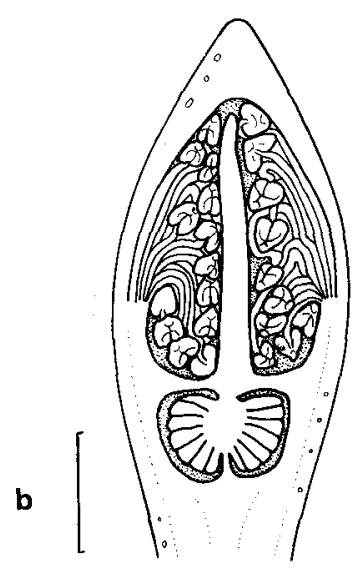

Figure 18. E. ralla. $a$, adult leaves and buds. $b$, median section of bud. $c, d$, anther. e, fruit. $f, g$, seed (all from Johnson, Blaxell \& Briggs 3139). Scale bar: $\mathrm{a}=1 \mathrm{~cm} ; \mathrm{b}, \mathrm{c}, \mathrm{d}, \mathrm{f}, \mathrm{g}=0.5 \mathrm{~mm} ; \mathrm{e}=5 \mathrm{~mm}$. 

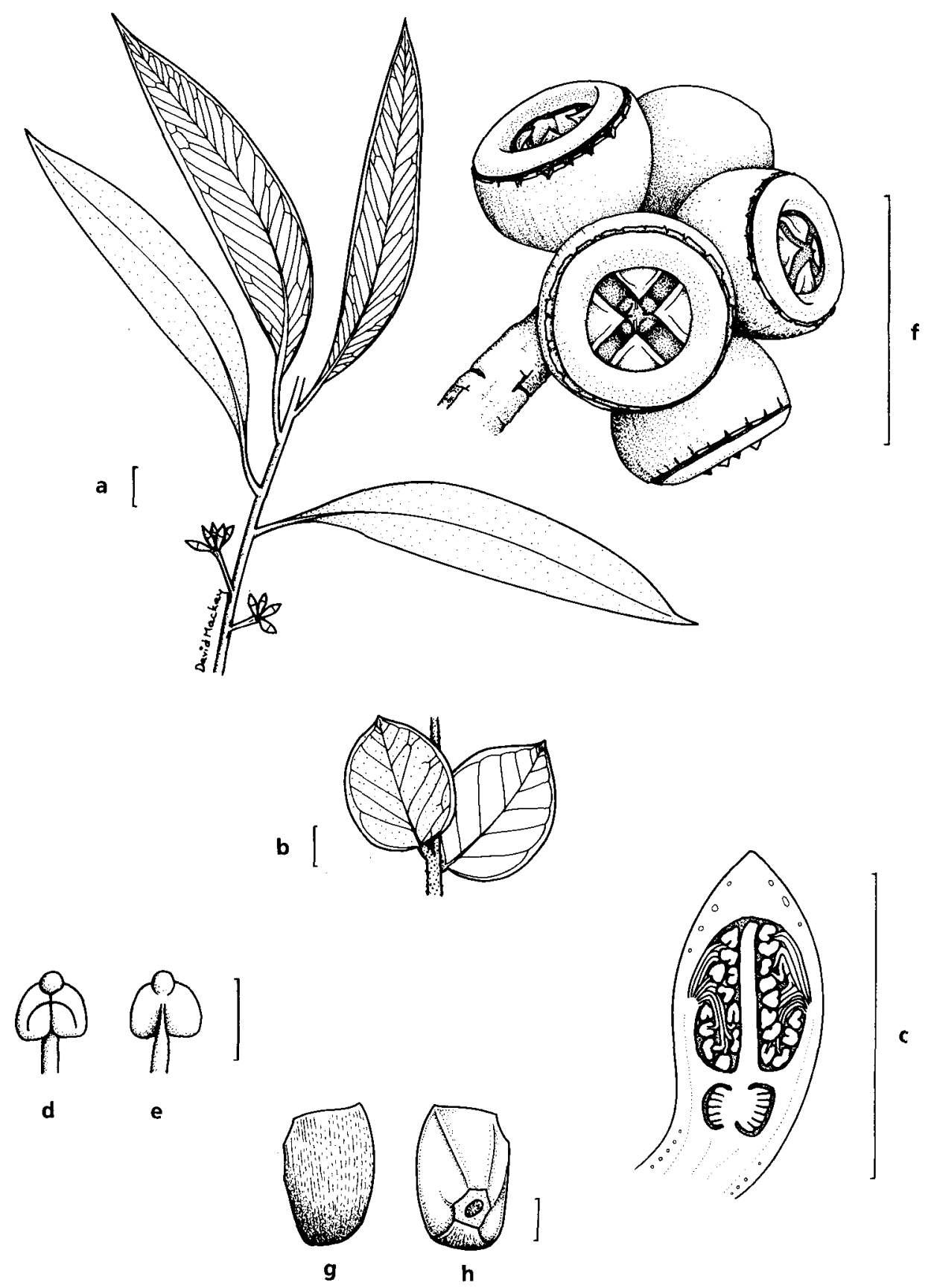

Figure 19. E. imitans. a, adult leaves and buds. $\mathbf{b}$, juvenile leaves. $\mathbf{c}$, median section of bud. $\mathbf{d}$, e, anther. f, fruit. g, h, seed (all from Johnson. Blaxell \& Briggs 3134). Scale bar: a, b, f=1 cm; c, $=5 \mathrm{~mm} ; \mathrm{d}, \mathrm{e}, \mathrm{g}, \mathrm{h}=0.5 \mathrm{~mm} ; \mathrm{e}=5 \mathrm{~mm}$. 
Distribution: Tallong to Nerriga, east to near Nowra (Figure 15).

ECoLogY: Locally abundant in low dry sclerophyll woodland on sandstone plateau country.

The epithet is from the Latin imitans, imitating, from the resemblance to E. oblonga.

CONSERVATION STATUS: not considered to be at risk.

Selected specimens (from 12 examined): New SOUth WALes: Central Tablelands: $17 \mathrm{~km}$ ESE of Tallong, Johnson 8376, 30 Oct 1977 (NSW). Southern Tablelands: Nerriga, Walker ANU 1158, Oct 1983 (CANB, NSW). South Coast: Yalwal Creek fire trail, Gilmour 5207, 11 Sep 1985 (CBG, MEL, NSW); 6 miles [9.6 km] W of Nowra on Yalwal road, Blaxell $1340 \&$ Johnson, 21 Apr 1974 (NSW); 15 miles [24 km] W of Nowra on Yalwal road, Johnson, Blaxell \& B.G. Briggs 3134, 18 Dec 1969 (NSW).

\section{Eucalyptus spectatrix L. Johnson $\mathcal{E}$ Blaxell, sp. nov.}

Affinis. E. dendromorphae sed combinatione characterum sequentium distinguitur: folia minora venatione minus prominenti et folia juvenilia lanceolata minora. Folia majora quam illa $E$. strictae sunt.

Type: New South Wales: South Coast: $2 \mathrm{~km}$ due east of Mumbulla Trig, NE of Bega, D.F. Blaxell 1761, 2 May 1979 (holo NSW; iso AD, BRI, CANB, HO, K, MEL, PERTH).

Mallee to $6 \mathrm{~m}$ high. Bark smooth, grey-brown and cream, shedding in strips. Juvenile leaves disjunct, lanceolate, falcate, to $13 \mathrm{~cm}$ long, $2 \mathrm{~cm}$ wide, venation and oil glands distinct, lateral veins at $20-30^{\circ}$ to midrib. Adult leaves disjunct, lanceolate, oblique, falcate, attenuate, coriaceous, $7-13 \mathrm{~cm}$ long, 1-2 cm wide; petioles flattened, 6-10 $\mathrm{mm}$ long; lateral and intramarginal veins indistinct; oil glands large and prominent. Umbellasters axillary, 7-flowered; peduncles 2-angled, 1-15 mm long; pedicels terete or vaguely angular, 1-3 mm long. Mature buds irregularly pyriform, verrucose, 7-10 mm long, 4-5 mm diam.; calyptra convex, obtuse, less than $1 / 4$ as long as hypanthium. Fruits urceolate to cup-shaped, usually apically constricted, 4-locular, 8-11 $\mathrm{mm}$ long, 8-10 $\mathrm{mm}$ diam.; calyptra scar a narrow groove around hypanthium; stemonophore narrow, raised above disc and hypanthium; disc at first sharply depressed, becoming flat, up to $2 \mathrm{~mm}$ wide; valves fully enclosed, vertical when opened. Seeds grey-brown or brown, reniform, angular, to $2 \mathrm{~mm}$ long; chaff similar.

E. spectatrix differs from E. dendromorpha (Blakely) L. Johnson \& Blaxell in the narrower juvenile leaves (broad-lanceolate in the latter) and the consistent mallee habit. The leaves and fruits are larger than in the related mallee species E. stricta Sieber ex Sprengel (which has adult leaves 6-10 cm long, 6-10 mm wide, and fruit 7-10 $\mathrm{mm}$ long, 6-8 mm diam.).

Distribution: New South Wales: Known from a few mountain tops in the Bega district, southern South Coast (Figure 20).

ECOLOGY: This species occurs in crevices with very little soil on rocky granite hilltops, usually in a scleromorphic shrub community.

The epithet is from the Latin, spectatrix, she who observes, referring to the occurrence of this species on prominent, bare hill tops. It is used as a noun, not an adjective.

Conservation STATUs: $2 \mathrm{RC}$. The limited stands of this taxon occur in relatively secure habitats.

Selected specimens (from 16 examined): New SOuth Wales: South Coast: Dr George Mtn, Hill 1358 $\mathcal{E}$ Johnson, 16 Feb 1986 (NSW), Brooker 6946, 19 May 1980 (CANB, NSW); 4 km N of Mumbulla Mtn, Miller, 16 Jun 1978 (NSW); 6.6 km E of Bemboka Peak, Albrecht 2954, 4 Nov 1986 (MEL, NSW). 
19. Eucalyptus laophila L. Johnson E Blaxell, sp. nov.

Affinis E. apiculatae sed foliis longioribus aliquanto glaucolucentibus et fructibus saepe majoribus differt.

Type: New SOUth WaLes: Central Tablelands: Wolgan Gap, L. Johnson, 12 Apr 1953 (holo NSW 27182).

Mallee to $6 \mathrm{~m}$ high. Bark smooth, grey-brown and cream, shedding in strips. Juvenile leaves disjunct, lanceolate, falcate, to $13 \mathrm{~cm}$ long, $2 \mathrm{~cm}$ wide, venation and oil glands distinct, lateral veins at $20-30^{\circ}$ to midrib. Adult leaves disjunct, lanceolate, oblique, falcate, attenuate, coriaceous, glossy green, usually with a bluish sheen, $7-13 \mathrm{~cm}$ long, $1.0-2.0 \mathrm{~cm}$ wide; petioles flattened, 6-10 mm long; lateral and intramarginal veins indistinct; oil glands large and prominent. Umbellasters axillary, 7-flowered; peduncles 2-angled, 1-15 mm long; pedicels terete or vaguely angular, 1-3 mm long. Mature buds clavate to pyriform, verrucose, 7-10 mm long, 4-5 mm diam.; calyptra convex, obtuse, apiculate, less than $1 / 4$ as long as hypanthium. Fruits urceolate to cup-shaped, usually apically constricted, 4-locular, 8-11 mm long, 8-10 mm diam.; calyptra scar a narrow groove around hypanthium; stemonophore narrow, raised above disc and hypanthium; disc at first sharply depressed, becoming flat, up to $2 \mathrm{~mm}$ wide; valves fully enclosed, vertical when opened. Seeds grey-brown or brown, reniform, angular, to $2 \mathrm{~mm}$ long; chaff similar. Figure 21.

Distinguished from E. apiculata by the bluish sheen in adult foliage, the larger and relatively broader adult leaves (i.e. lower length:breadth ratio) and the larger fruits. The latter two characters show some overlap (E. apiculata has adult leaves $5-10 \mathrm{~cm}$ long, 5-7 mm wide, and fruit 6-9 $\mathrm{mm}$ long, 6-8 $\mathrm{mm}$ diam.).

Distribution: Mt Coricudgy district to south of Newnes (Figure 20). It is disjunct from E. apiculata, which occurs from the Springwood district south to near Berrima and near Mt Keira.

ECOLOGY: Locally abundant in scleromorphic mallee heath on shallow sandy soils. This taxon characteristically occurs around the distinctive 'beehive' or 'pagoda' formations of weathered sandstone of the Triassic Narrabeen Group.

Hybrids and intergrades occur with E. stricta to a limited extent around the Newnes Plateau. The related E. apiculata also hybridises and intergrades with $E$. stricta in the northern and eastern parts of its range (Springwood and Mt Keira), but does not meet E. laophila.

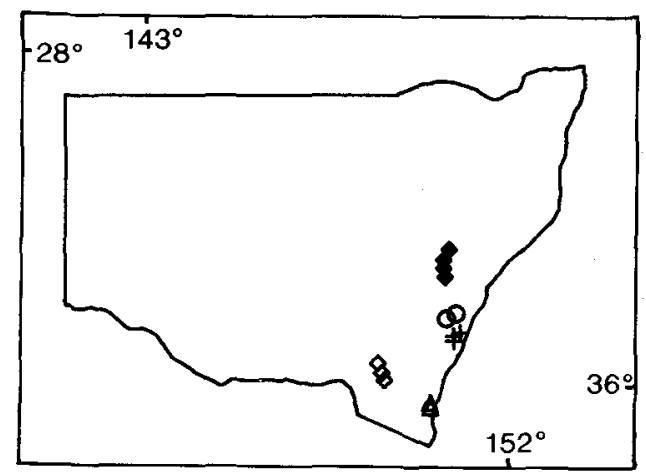

Figure 20. Distribution of E. spectatrix $(\triangle)$, E. laophila $(\diamond)$, E. apiculata $(O)$, E. langleyi $(+)$ and E. lacrimans $(\diamond)$. 


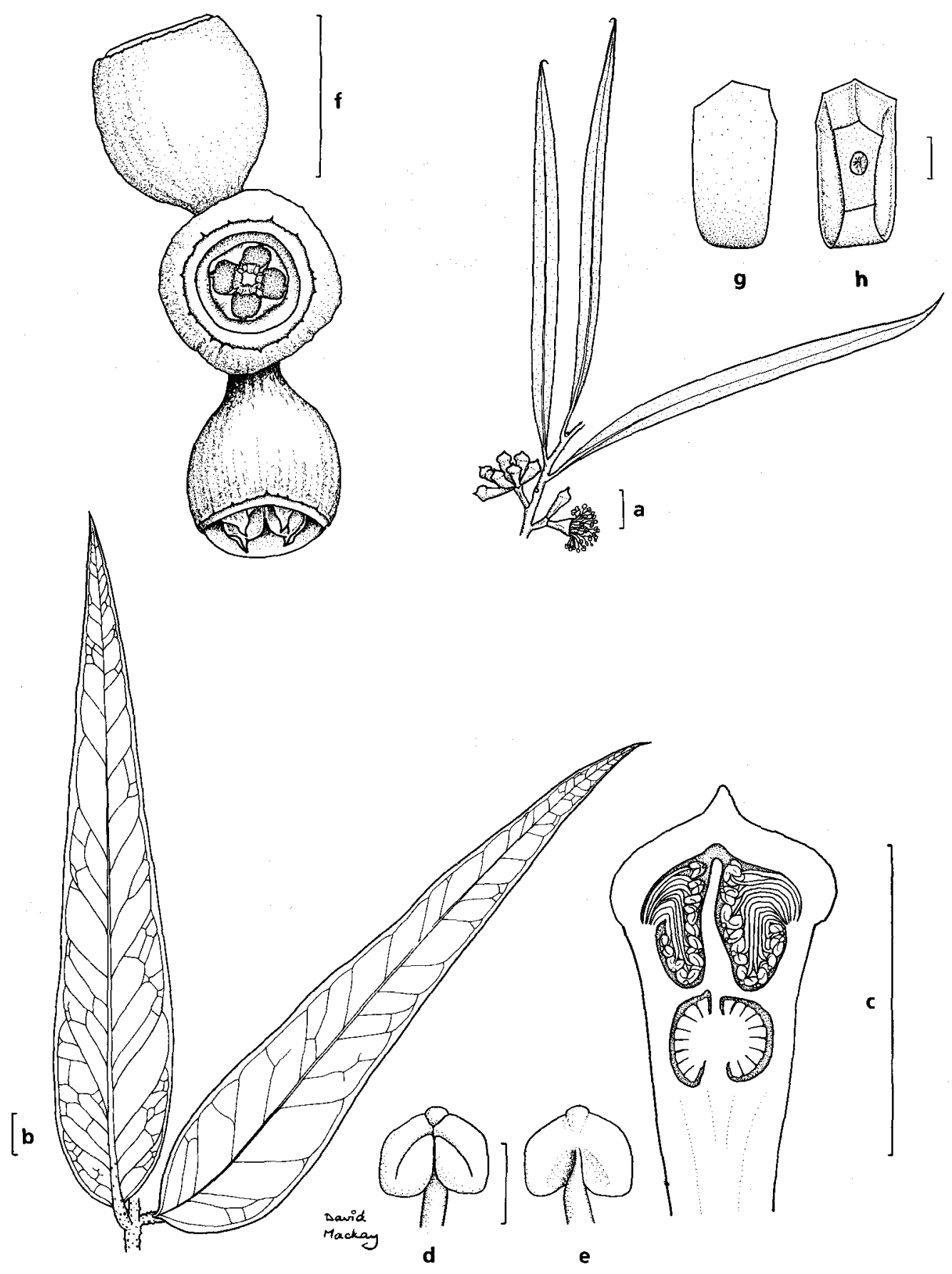

Figure 21. E. laophila. a, adult leaves, buds and flowers. $\mathbf{b}$, juvenile leaves. $\mathbf{c}$, median section of bud. d, e, anther. f, fruit. $\mathbf{g}$, h, seed (a, b, c, d, e from Crisp 1277, f, g, h from McGillivray \& Rodd R140). Scale bar: $a, b, f=1 \mathrm{~cm} ; c=5 \mathrm{~mm} ; \mathrm{d}, \mathrm{e}, \mathrm{g}, \mathrm{h}=0.5 \mathrm{~mm}$. 
The epithet is from the Greek laas or laos, a stone (not laos, people), and -philos, loving, from the species' occurrence among rocky outcrops. The stress is on the '- $\mathrm{o}^{-}$as in other '-ophilus' (but not '-ophyllus') epithets.

CONSERVATION STATUS: not considered to be at risk.

SeLECTED SPECIMENS (from 24 examined): NeW SOUTH WALES: Central Tablelands: firetrail between Kekeelbon and Coricudgy Mtns, McGillivray 1612, 13 Feb 1966 (NSW); Currant Mtn Gap, Rodd 2591, 30 Nov 1973 (NSW); Gospers Mtn road, 11 miles [18 km] from turnoff at Red Hill, McGillivray \& Rodd R140, 26 Apr 1965 (NSW); 1.5 km S of Kandos Weir, Crisp 1277, 4 Oct 1975 (CBG, NSW); Glow-worm Tunnel area, $35 \mathrm{~km}$ NNE of Lithgow, Hind 852, 29 Aug 1976 (NSW); $37 \mathrm{~km} \mathrm{~N}$ of Clarence on Newnes Tunnel road, Coveny 3565, 6 Apr 1971 (NSW).

\section{Eucalyptus obstans L. Johnson $\mathcal{E}$ K. Hill, sp. nov.}

Frutex vel arbuscula multicaulis. Cortex laevis. Folia juvenilia late lanceolata vel ovata. Folia adulta late lanceolata, 6-10 cm longa, 15-25 mm lata, petiolis 8-15 mm longis. Umbellastrae in axillis foliorum evolutorum, plerumque 7 -florae, pedunculis $7-15$ $\mathrm{mm}$ longis, pedicellis 1-5 mm longis. Alabastra clavata vel pyriformia, 7-9 mm longa, 5-7 mm diametro; calyptra paulo brevior quam hypanthium, verruculosa, plerumque apiculata. Fructus urceolati ad globulares, 10-13 mm longi, 8-11 $\mathrm{mm}$ diametro.

TYPE: New SOUTH Wales: Central Coast: $1 / 2$ mile [0.8 km] NW of Governor Game Lookout, Royal National Park, J. O'Hara \& R. Coveny 3560, 31 Mar 1971 (holo NSW; iso $\mathrm{CANB}, \mathrm{K})$.

[E. obtusiflora auct. non DC. (1828), Bentham (1867), et auct. plur.]

Maiden (1907) made the combination E. virgata Sieber ex Sprengel var. obtusiflora (DC.) Maiden based on de Candolle's name, understanding that de Candolle's type represented the eastern Australian species that we are naming E. obstans. All of Maiden's cited material is of this eastern taxon. De Candolle also apparently confused the taxa, his original type representing a Western Australian species (E. obtusiflora, until now known by its later synonym $E$. dongarraensis Maiden \& Blakely). Other material he later cited represents E. obstans (Sieber 473, cited in Mém. Myrt., 1842).

[E. obtusifolia sphalm., G. Don (1832)]

[E. rigida Sieber ex Benth., Fl. Austral. 3: 205 (1867), in syn., nom. nud.; R. Br. ex Maiden, Crit. Revis. Eucalyptus 1: 273 (1907), in syn., nom. nud.; non Hoffsgg. (1826)]

Mallee to $4 \mathrm{~m}$ tall. Bark smooth. Juvenile leaves broad-lanceolate to ovate. Adult leaves broad-lanceolate, 6-10 cm long, 15-25 mm wide; petioles 8-15 mm long. Inflorescences simple, axillary, umbellasters usually 7-flowered; peduncles $7-15 \mathrm{~mm}$ long; pedicels 1-5 mm long. Buds clavate to pyriform, 7-9 mm long, 5-7 mm diam.; calyptra slightly shorter than hypanthium, finely verrucose, usually apiculate. Fruits urceolate to globular, 10-13 mm long, 8-11 $\mathrm{mm}$ diam.

Nearest to E. stricta, from which it differs in the broad-lanceolate adult and juvenile leaves (both lanceolate or narrower in E. stricta), and the larger buds and fruits (buds to $4 \mathrm{~mm}$ diam., fruit to $8 \mathrm{~mm}$ diam. in E. stricta). The related E. dendromorpha differs in the tree habit and the smaller buds (to $7 \mathrm{~mm}$ long, $4 \mathrm{~mm}$ diam.).

Intergrading populations occur with E. dendromorpha (Blakely) L. Johnson \& Blaxell and E. stricta Sieber ex Sprengel. Hybrids are recorded with E. luehmanniana F. Muell. (named as E. virgata Sieber ex Sprengel and E. sieberiana F. Muell.) and E. sieberi L. Johnson. Hybrids are also recorded between E. obstans - E. stricta intergrades and E. triflora (Maiden) Blakely. 
The epithet is from the Latin obstans, hindering or obstructing, referring to the thick scrubs formed by the species, and is chosen for mnemonic reasons to continue the association with ' $\mathrm{ob}$ '.

CONSERvation STATUS: not considered to be at risk, but now very scarce in the Port Jackson district.

Selected sPECimens (from 120 examined): NeW SOUth Wales: Central Coast: 1 mile [1.6 km] NW of Berowra railway station, Shiress, 17 Aug 1919 (NSW 26841); Manly, Boorman, Nov 1917 (NSW 26944); Bondi sandhills, Blakely, 25 Apr 1917 (NSW 26951); La Perouse Road, Botany, Camfield, 4 Dec 1899 (NSW 26840); Karloo Pool to Uloola Falls, Royal National Park, Johnson, 10 Sep 1950 (NSW 26973); below Stanwell Tops, Pearson, 14 May 1981 (NSW). South Coast: Myall Creek Plateau, N of Nerriga, Whaite 3523, 28 Jul 1973 (NSW); Rotary Lookout, on Porters Creek Dam road, NW of Milton, Lowe 299, 300, 21 Nov 1977 (NSW); $13 / 4$ miles [2.5 km] SSE of police station, Jervis Bay, Hall FRI 20130, 17 Aug 1971 (CANB, NSW). Central Tablelands: Barren Grounds Nature Reserve, Coveny 11637, 25 Sep 1983 (NSW). Southern Tablelands: $2 \mathrm{~km}$ N of Pigeon House Mountain, Lowe 298, 21 Nov 1977 (NSW).

\section{Eucalyptus langleyi L. Johnson \& Blaxell, sp. nov.}

Affinis E. burgessianae sed combinatione characterum sequentium distinguitur: folia juvenilia late lanceolata vel ovata, folia adulta alabastra fructusque omnes majora, et ramuli distincte alati.

TYPE: New SOUTH Wales: South Coast: $1 \mathrm{~km}$ along Christmas Bush firetrail, off Nowra - Yalwal road, D.F. Blaxell 1244 \& D.H. Benson, 6 Feb 1974 (holo NSW).

Mallee to $5 \mathrm{~m}$ high. Bark smooth, brown, shedding in long ribbons. Young shoots prominently 4-winged. Juvenile leaves glossy green, broad-lanceolate to ovate. Adult leaves disjunct, lanceolate, acuminate, sometimes oblique, coriaceous, glossy green, $8-18 \mathrm{~cm}$ long, $1.8-4.0 \mathrm{~cm}$ wide; petioles $8-18 \mathrm{~mm}$ long, winged, wings decurrent with wings on twigs; lateral veins obscure, anastomosing, at $10-20^{\circ}$ to midrib; intramarginal vein obscure, leaf margin prominently thickened. Umbellasters axillary, 7-flowered; peduncles broadly winged, 8-12 $\mathrm{mm}$ long, to $7 \mathrm{~mm}$ wide apically; pedicels $0-2 \mathrm{~mm}$ long, angular. Mature buds irregularly pyriform, rugose, $11-14 \mathrm{~mm}$ long, 4-6 mm diam.; calyptra less than $1 / 4$ as long as hypanthium, hemispherical, very broadly obtuse. Stamens all fertile; filaments inflexed into hypanthium in bud; anthers dorsifixed, versatile, reniform, dehiscing through confluent slits. Fruits cup-shaped, 3- or 4-locular, sometimes apically constricted, 8-10 $\mathrm{mm}$ long, 8-10 $\mathrm{mm}$ in diameter, sometimes with 1-3 vertical ridges; calyptra scar a narrow groove around hypanthium, stemonophore $0.5-1 \mathrm{~mm}$ wide, flat, ultimately depressed to meet disc; disc enclosed, flat, 1-1.5 mm wide; valves enclosed, tips often exserted. Seeds dull, greybrown, angular, reniform, to $2.5 \mathrm{~mm}$ long; chaff similar, smaller. Figure 22.

E. langleyi differs from E. burgessiana L. Johnson \& Blaxell in the ovate juvenile leaves, the broader adult leaves (less than $25 \mathrm{~mm}$ wide in the latter), larger buds (7-10 $\mathrm{mm}$ long, 3-4 $\mathrm{mm}$ wide in the latter), and the distinctly winged shoots.

Distribution: NEW SOUTH WALES: Northern South Coast, immediately inland from Nowra (Figure 20).

Ecology: Locally common on shallow, poorly drained soil over sandstone or associated with laterite, on plateaux in highly dissected areas, often in heath patches surrounded by woodland of E. gummifera (Sol. ex Gaert.) Hochr., E. consideniana Maiden and a 'Scribbly Gum' under study.

Early collectors confused this species with E. luehmanniana F. Muell. because of the large leaves, buds and fruit and the winged stems. The morphology of the juvenile 

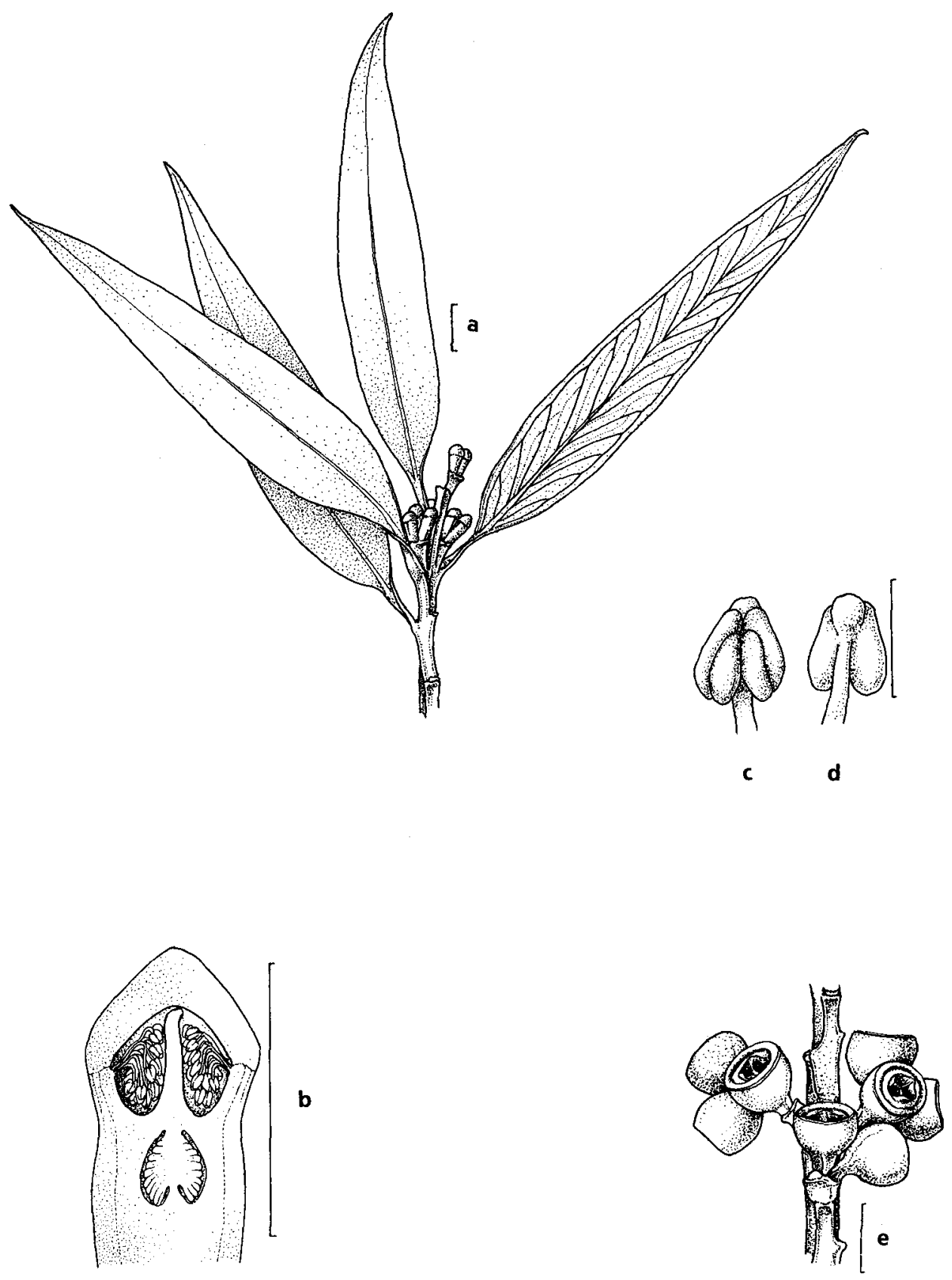

Figure 22. E. langleyi. a, adult leaves and buds. $\mathbf{b}$, median section of bud. $\mathbf{c}, \mathfrak{d}$, anther. e, fruit (all from Blaxell 1244). Scale bar: $\mathrm{a}, \mathrm{e}=1 \mathrm{~cm} ; \mathrm{b}=5 \mathrm{~mm} ; \mathrm{c}, \mathrm{d}=0.5 \mathrm{~mm}$. 
leaves and seeds, however, confirm its place with the 'Green Ash' group, clearly distinct from E. luehmanniana. This is also evident from microscopic examination of adult leaf surfaces, which are virtually identical with those of E. burgessiana, its apparent sister species.

The specific epithet honours Lawrence Langley, of Robertson, who first drew our attention to this taxon.

Conservation status: $2 \mathrm{~V}$. This taxon occurs in small stands in unreserved country. The habitat is unlikely to be threatened by agriculture, but at risk from residential and recreational development.

SELECTED SPECIMENS (from 12 examined): New SOUth Wales: Central Coast: Bomaderry walking track, Mills 13, 7 Apr 1985 (NSW). South Coast: $8.5 \mathrm{~km} \mathrm{~N}$ of Nerriga - Tomerong road on Nowra road, J.D. Briggs 32, 21 Sep 1977 (CANB, NSW); 10.1 miles [16.2 km ] from Princes Hwy at Nowra on Braidwood road, Hall 9, 4 Aug 1971 (CANB, NSW); c. 3 miles [5 km] SW of H.M.A.S. Albatross on Nowra-Nerriga road, Johnson \& Blaxell 60a, 7 Dec 1968 (NSW).

\section{Eucalyptus copulans L. Johnson $\mathcal{E} K$. Hill, sp. nov.}

$\mathrm{Ab}$ E. stellulata habitu minore, foliis juvenilibus adultisque minora angustioraque, disco depresso, et ab E. moorei habitu majore, foliis majoribus distantioribus, distinguitur.

TYPe: New South WALES: Central Tablelands: Wentworth Falls, at head of creek just west of railway station, L. Johnson $\mathcal{E}$ E. Constable, 24 July 1957 (holo NSW 19267).

Tree to $6 \mathrm{~m}$ high. Bark smooth, grey. Juvenile leaves disjunct, narrow-elliptical, apiculate, to $6.5 \mathrm{~cm}$ long, $2.5 \mathrm{~cm}$ wide; petioles $2-7 \mathrm{~mm}$ long. Adult leaves disjunct, lanceolate to oblanceolate, acute, $6-12 \mathrm{~cm}$ long, $1.0-1.8 \mathrm{~cm}$ wide; petioles $5-10 \mathrm{~mm}$ long; venation well-spaced, several subparallel, anastomosing veins arising from base. Umbellasters axillary, more than 7-flowered; peduncles terete, 3-8 $\mathrm{mm}$ long; pedicels 0-1 mm long. Mature buds cylindrical, up to $8 \mathrm{~mm}$ long, $2.5 \mathrm{~mm}$ in diameter; calyptra conical, acute, as long as hypanthium. Stamens all fertile; anthers reniform, dorsifixed, versatile, dehiscing by confluent slits. Fruits globular, 3-locular, 4-6 mm long, c. $5 \mathrm{~mm}$ diam.; calyptra scar and stemonophore distinct, forming a narrow groove around top of fruit; disc discontinuous with hypanthium, c. $1 \mathrm{~mm}$ wide, depressed; valves deeply enclosed. Seeds dark brown, dull, reniform, rounded, to $2 \mathrm{~mm}$ long; chaff similar, slightly smaller.

Distribution: New South Wales: Wentworth Falls, Central Tablelands.

Ecology: Known from a single population growing in a swampy site near a creek on a sandstone plateau. This population appears to have been completely destroyed in the years following 1957, and the species must be presumed to be extinct. The late Rev. Colin Burgess at one time had it in cultivation at Leura, but his plants perished.

$E$. copulans is nearest to E. stellulata Sieber ex DC., differing in the smaller habit, the narrower juvenile leaves (ovate to orbicular in the latter), the narrower adult leaves (elliptical to broad-lanceolate in the latter), and the depressed disc. The habitats also differ, that of $E$. copulans being similar to the preferred habitat of $E$. moorei Maiden \& Cambage. It differs from $E$. moorei in the tree habit, larger, broader leaves and depressed disc. E. copulans is intermediate in many characters between E. moorei and E. stellulata, but formed a uniform population that was geographically distant from the nearest populations of E. moorei and E. stellulata. It is therefore not simply a hybrid, and in view of its distinct and uniform differences must be regarded as equally removed from both E. moorei and E. stellulata. Some hybrids of $E$. copulans with nearby stringybarks, probably E. ligustrina $x$ E. sparsifolia, were formerly also 
present at the site.

The epithet is from the Latin copulans, joining, referring to the link between $E$. moorei and E. stellulata formed by this species.

CONSERVATION STATUS: $X$, see above. It is of course conceivable that other occurrences may yet be found in swampy sites on the Blue Mountains plateau.

Specimens examined: New South Wales: Central Tablelands: Wentworth Falls near railway station, Camfield, Mar 1899 (NSW); Wentworth Falls, Burgess, July 1951 (NSW).

\section{Eucalyptus serpentinicola L. Johnson \& Blaxell, sp. nov.}

$\mathrm{Ab}$ E. moorei foliis juvenilibus adultisque longioribus angustioribusque et foliis adultis ramulisque laxis saepe pendulis distinguitur.

TyPE: New SOUTH Wales: North Coast: serpentine hills c. $5 \mathrm{~km}$ NW of Curricabark, L. Johnson 7633 \& R. Coveny, 21 Mar 1973 (holo NSW; iso BRI, CANB, MEL, K).

Mallee to $6 \mathrm{~m}$ high, usually less. Bark smooth, brown, grey-brown, olive-brown. Foliage often lax or pendent. Juvenile leaves opposite or disjunct, linear to lanceolate, acute, sessile, to $6 \mathrm{~cm}$ long, $7 \mathrm{~mm}$ wide. Adult leaves disjunct, linear to narrow-lanceolate, acute or acuminate, 4-12 cm long, 4-10 $\mathrm{mm}$ wide; petioles 0-7 mm long; venation sub-parallel, obscure. Umbellasters axillary, 7-flowered or usually more; peduncles terete, 5-10 mm long. Pedicels 0-1 mm long. Mature buds cylindrical, c. 7 $\mathrm{mm}$ long, c. $2.5 \mathrm{~mm}$ diam.; calyptra conical, as long as hypanthium. Stamens all fertile; filaments erect then inflexed in bud; anthers reniform, dorsifixed, versatile, dehiscing by confluent slits. Fruits globular, 3-locular, 4-5 mm long, 4-5 mm diam.; calyptra scar and stemonophore a narrow groove around hypanthium; disc 0.5 to $1 \mathrm{~mm}$ wide, flat or shallowly depressed, discontinuous with hypanthium; valves deeply enclosed. Seeds dark brown, dull, angular, reniform, to $1.5 \mathrm{~mm}$ long; chaff similar, much smaller. Figure 23.

E. serpentinicola is nearest to E. moorei, differing in the longer and relatively narrower adult leaves (to $7 \mathrm{~cm}$ long and narrow-lanceolate to lanceolate in the latter) and the lax, somewhat bluish green, often pendulous foliage. The dry habitat is also different from the commonly wet, swampy habitat of E. moorei. The related mallee species E. latiuscula differs from both in the broader adult and juvenile leaves.

Distribution: New SOUth WALEs: Coastal ranges of the Curricabark area in the southwestern North Coast district (Figure 24).

ECOLOGY: Locally common on skeletal soils over steep serpentinite hills, associated with Xanthorrhoea glauca Bedford subsp. glauca and Triodia irritans R. Br. It was first brought to notice by Mr E.L. Hyem, a grazier near Curricabark, who took a particular interest in the 'serpentine' country.

The epithet is from the Latin serpentinus, relating to a serpent, and the suffix -cola, '-dweller', referring to the restricted occurrence of the species on serpentinitederived soils. The epithet is a noun, not an adjective.

CONSERVATION STATUS: $2 \mathrm{R}$. Although not conserved, the habitat of this taxon is relatively secure.

Selected specimens (from 7 examined): New South Wales: North Coast: $4 \mathrm{~km}$ direct $\mathrm{N}$ of Curricabark, J.D. Briggs 226 \& Pryor, 21 Feb 1979 (CANB, NSW); Watchimbark Ck, 'Myra', Blaxell 13, 14 \& Coveny, 21 Sep 1968 (NSW). Northern Tablelands: Bralga Tops, 'Glenrock' Station, Blaxell 1834 \& Johnson, 24 Mar 1981 (NSW). 

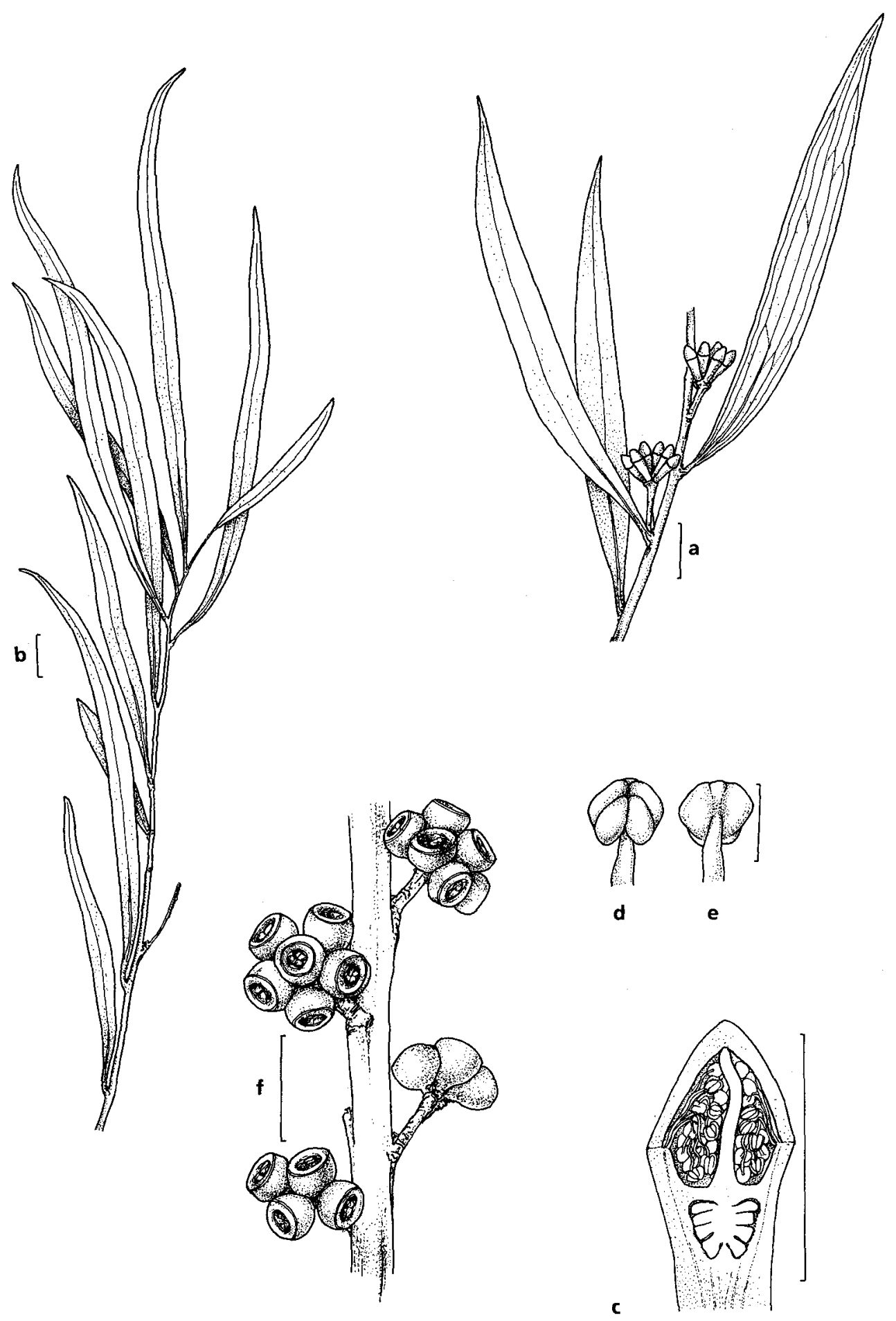

Figure 23. E. serpentinicola. a, adult leaves and buds. b, juvenile leaves. $\mathbf{c}$, median section of bud. d, e, anther. $\mathbf{f}$, fruit (from Blaxell $13 \mathcal{E}$ 14). Scale bar: $a, b, f=1 \mathrm{~cm} ; c=5 \mathrm{~mm} ; \mathrm{d}$, e = $0.5 \mathrm{~mm}$. 
24. Eucalyptus lacrimans L. Johnson $\mathcal{E} K$. Hill, sp. nov.

Inter complexum specierum affinitatis $E$. pauciflorae habitu distincto ramulis lacrimantibus foliis valde separatis distinguitur.

Type: New South Wales: Southern Tablelands: $12.6 \mathrm{~km} \mathrm{~N}$ of Rules Point on Long Plain, K. Hill 740, L. Johnson \& L. Pryor, 27 Apr 1984 (holo NSW; iso BRI, CANB, K, MEL).

Tree to $12 \mathrm{~m}$ high. Bark smooth, white and grey. Branchlets glaucous. Juvenile leaves disjunct, broad-lanceolate to ovate, apiculate, to $15 \mathrm{~cm}$ long, $7 \mathrm{~cm}$ wide; petioles 3-7 $\mathrm{mm}$ long. Adult leaves disjunct, narrow-lanceolate to lanceolate, acuminate, $7-15 \mathrm{~cm}$ long, $0.7-2.0 \mathrm{~cm}$ wide; petioles $7-16 \mathrm{~mm}$ long; venation well-spaced, several subparallel, anastomosing veins arising from base. Umbellasters axillary, 7-flowered; peduncles terete or weakly angular, 4-10 mm long; pedicels 0-3 mm long. Mature buds glaucous, clavate, 5-7 mm long, 3-4 mm diam.; calyptra hemispherical or broadly conical, obtuse, slightly shorter than hypanthium. Stamens all fertile; anthers reniform, dorsifixed, versatile, dehiscing by confluent slits. Fruits cup-shaped or obconic, 3-4-locular, 8-10 mm long, 8-10 mm diam.; calyptra scar and stemonophore distinct, forming a narrow raised band around top of fruit; disc flat, 1-2 mm wide; valves enclosed. Seeds brownish black, dull, reniform, rounded, to $2 \mathrm{~mm}$ long; chaff similar, slightly smaller and paler. Figure 25.

Distinguished from E. pauciflora Sieber ex Sprengel by the strongly glaucous twigs and buds, and from E. niphophila Maiden \& Blakely by the very pendulous branches with elongated internodes.

Distribution: New South Wales: Restricted to the Adaminaby-Kiandra district on the Southern Tablelands (Figure 20).

ECOLOGY: Locally common in small, open copses on broad, flat and usually more or less treeless grassy plains, with Poa understorey. Such plains form a mosaic with E. pauciflora - E. rubida subsp. rubida woodlands on higher country in the same area.

Some hybridism with E. pauciflora is evident where populations adjoin.

CONSERVATION STATUS: 2R. Substantial populations of this taxon are now reserved.

The epithet is from the Latin lacrimans, weeping, in reference to the distinctively pendulous branchlets.

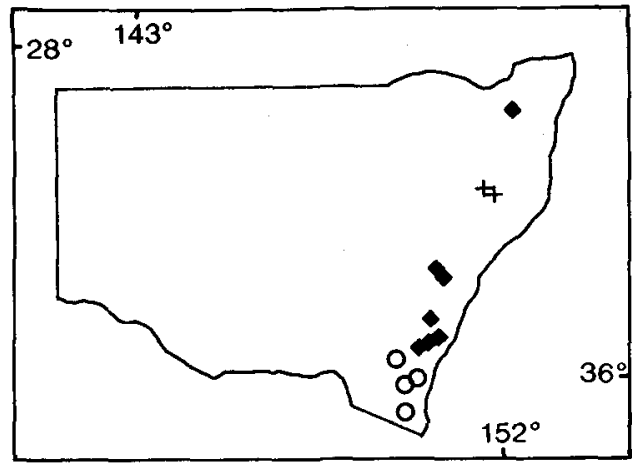

Figure 24. Distribution of E. serpentinicola $(+)$, E. moorei $(\bullet)$ and E. Jatiuscula $(O)$. 


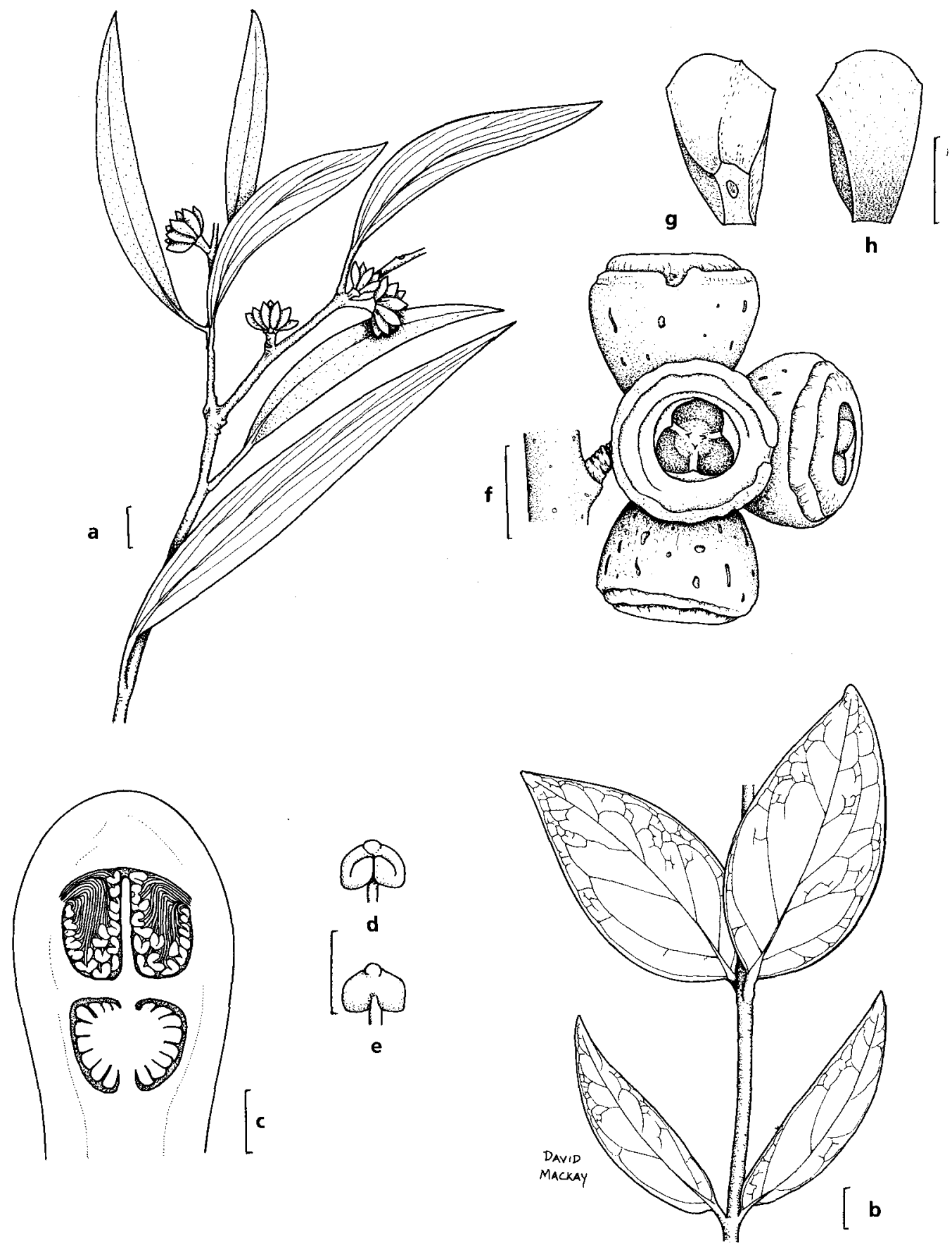

Figure 25. E. lacrimans. $\mathbf{a}$, adult leaves and buds. $\mathbf{b}$, juvenile leaves. $\mathbf{c}$, median section of bud. $\mathbf{d}$, $\mathbf{e}$, anther. f, fruit. $g, h$, seed (all from Hill 740 , Johnson \& Pryor). Scale bar: $a, b=1 \mathrm{~cm} ; f=5 \mathrm{~mm}$; $c=1 \mathrm{~mm} ; \mathrm{d}, \mathrm{e}, \mathrm{g}, \mathrm{h}=0.5 \mathrm{~mm} ; \mathrm{e}=5 \mathrm{~mm}$. 
Selected SPECIMENS (from 12 examined): NeW SOUTH WALES: Southern Tablelands: $5 \mathrm{~km}$ ESE of Yarrangobilly, Taylor 1319, Jackson \& Hadlow, 4 Feb 1981 (CBG, NSW); $4 \mathrm{~km}$ SE of New Adaminaby, L. Johnson 8411 \& A. Johnson, 24 Apr 1978 (NSW, BRI, CANB, K, MEL); Tantangara airstrip, Coveny 5452, 23 Mar 1974 (NSW); Pocket Saddle, head of Goodradigbee River, Rodd 1663, 13 Apr 1971 (NSW).

\section{Acknowledgements}

Our colleague, Don Blaxell, has contributed in the recognition of many of the new taxa, and is co-author of several species. Thanks are due to Leonie Stanberg, who has provided invaluable assistance through the project and drafted the distribution maps. David Mackay prepared most of the illustrations, and Bob Roden prepared the illustrations of E. parramattensis subsp. decadens, E. lockyeri and E. serpentinicola. Lani Retter provided much assistance in earlier stages of the investigations. The work was in part supported by grants from the Australian Biological Resources Study, which are gratefully acknowledged.

\section{References}

Blakely, W.F. (1934) A key to the eucalypts (The Worker Trustees: Sydney).

Bramwells, H.W. \& Whiffin, T. (1984) Patterns of variation in E. sideroxylon A. Cunn. ex Woolls. 1. Variation in adult morphology. Austral. J. Bot. 32(3): 263-281.

Briggs, J.D. \& Leigh, J.H. (1988) Rare or threatened Australian plants. Revised Edition. Australian National Parks and Wildlife Service, Special Publication 14.

Chippendale, G.M. (1988) Flora of Australia Volume 19, Eucalyptus, Angophora (Myrtaceae) (Australian Government Publishing Service: Canberra).

Johnson, L.A.S. (1972) Evolution and classification in Eucalyptus. Proc. Linn. Soc. New South Wales 97: 11-29.

Johnson, L.A.S. \& Briggs, B.G. (1984) Myrtales and Myrtaceae - a phylogenetic analysis. Ann Missouri Bot. Gard. 71: 700-756.

Johnson, L.A.S. \& Hill, K.D. (1990) New taxa and combinations in Eucalyptus (Myrtaceae). Telopea 4(1): 37-108.

Ladiges, P.Y. (1984) A comparative study of trichomes in Angophora Cav. and Eucalyptus L'Hérit. Austral. J. Bot. 32: 561-574.

Maiden, J.H. (1907) Forest flora of New South Wales, Vol. 3, part 25 (Govt Printer: Sydney).

McVaugh, R. (1968) The genera of American Myrtaceae - an interim report. Taxon 17: 354-418. Mueller, F. (1880) Eucalyptographia 8 (Govt Printer: Melbourne).

Pryor, L.D. \& Johnson, L.A.S. (1971) A classification of the eucalypts (ANU Press: Canberra).

\section{Index}

New names and combinations are printed in boldface, synonyms are printed in italics.

Eucalyptus alligatrix

Eucalyptus caleyi

Eucalyptus caleyi subsp. caleyi

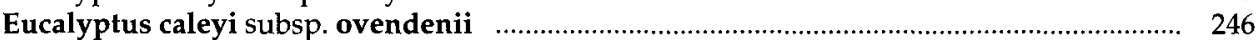

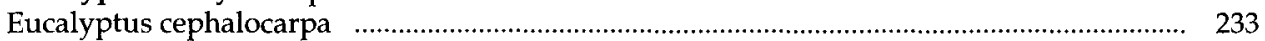

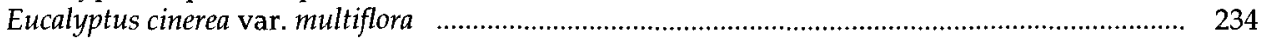

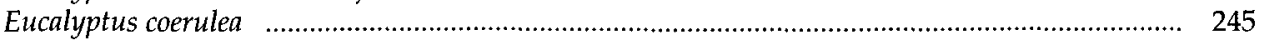

Eucalyptus conspicua $\quad$................................................................................................ 235

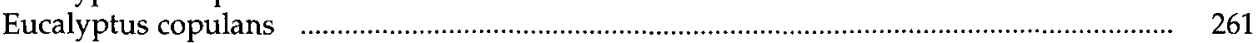

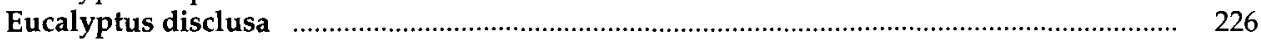

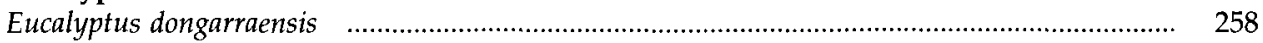




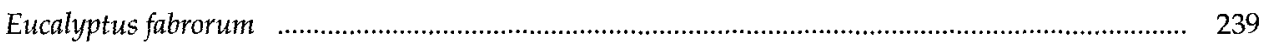

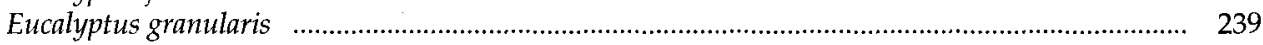

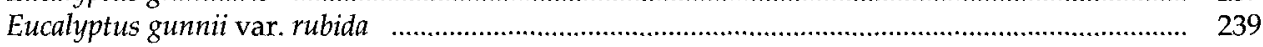

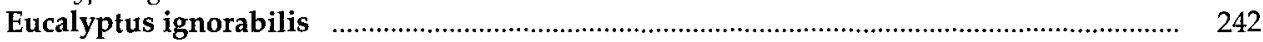

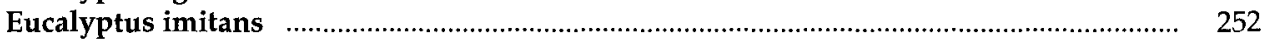

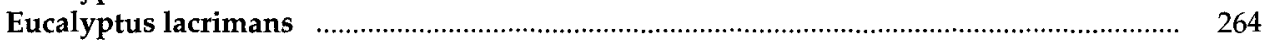

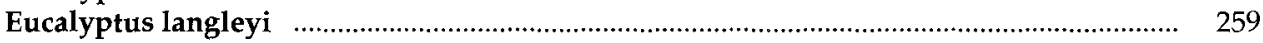

Eucalyptus laophila

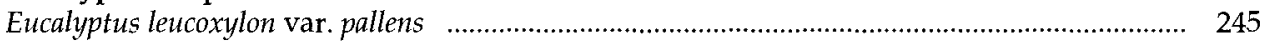

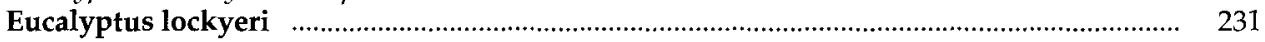

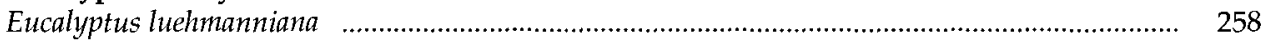

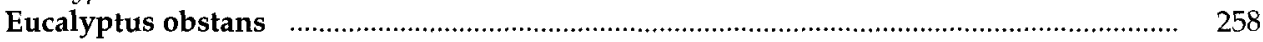

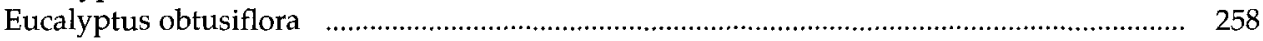

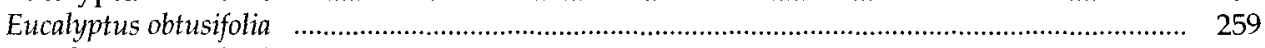

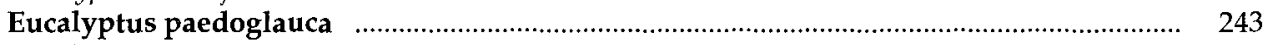

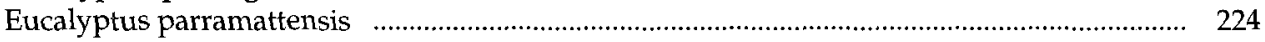

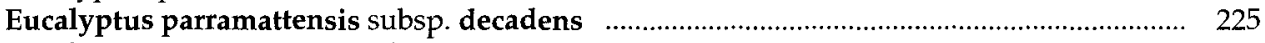

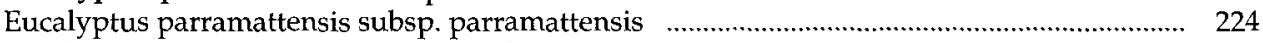

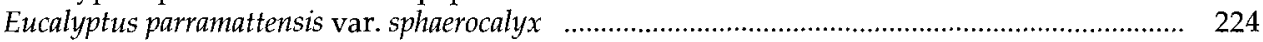

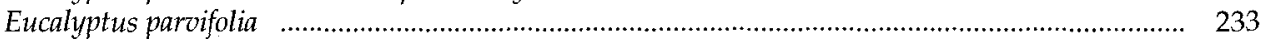

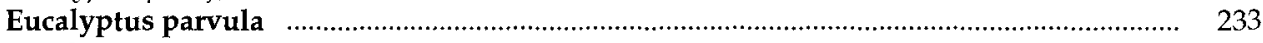

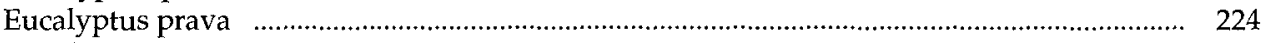

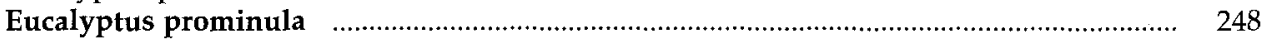

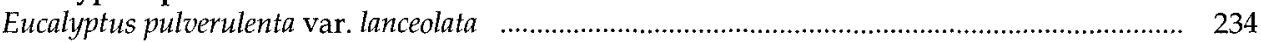

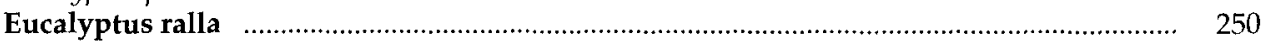

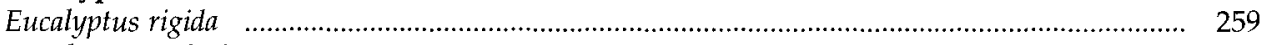

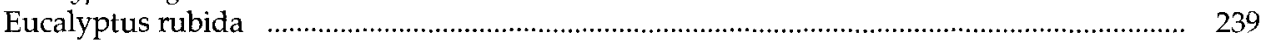

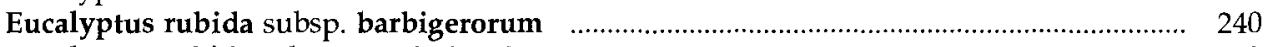

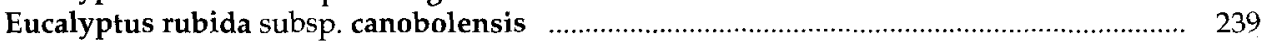

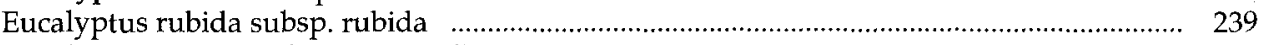

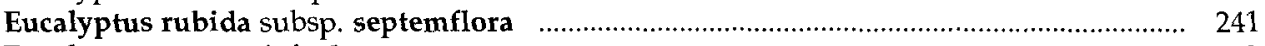

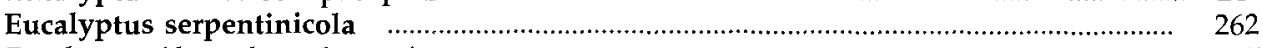

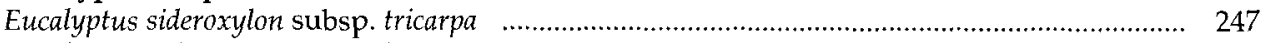

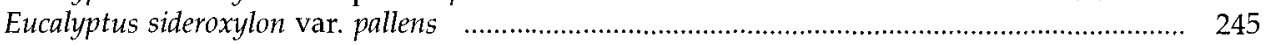

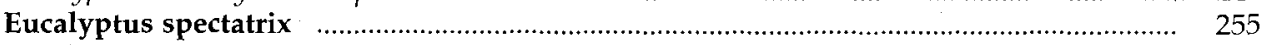

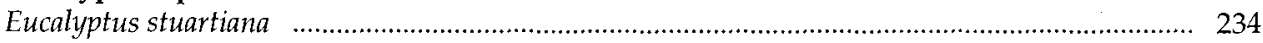

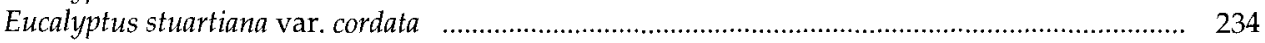

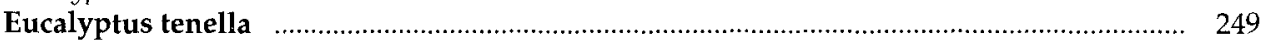

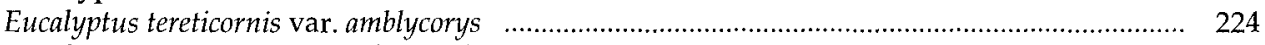

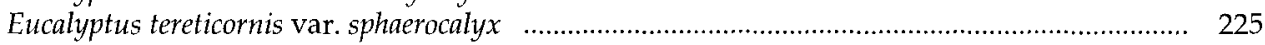

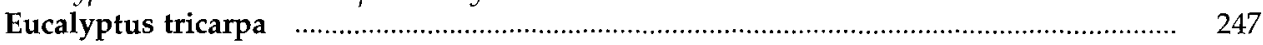

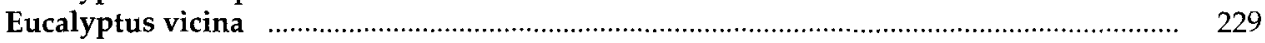

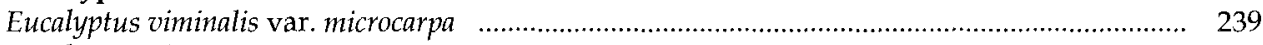

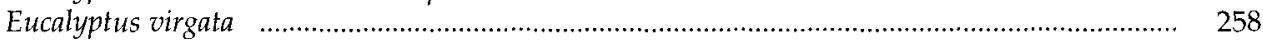

Manuscript received 20 June 1990

Manuscript accepted 20 November 1990 